NBER WORKING PAPER SERIES

THE IMPACT OF CHIEF DIVERSITY OFFICERS ON DIVERSE FACULTY HIRING

\author{
Steven W. Bradley \\ James R. Garven \\ Wilson W. Law \\ James E. West \\ Working Paper 24969 \\ http://www.nber.org/papers/w24969 \\ NATIONAL BUREAU OF ECONOMIC RESEARCH \\ 1050 Massachusetts Avenue \\ Cambridge, MA 02138 \\ August 2018
}

Thanks to the Baugh Center for Free Enterprise and the Baylor Department of Economics for financial support. Thanks to H. Bradley, C. Brown, E. Corey, Y. Liu, J. Meer, C. North, K. Renois, I. Udoetok, S. Zaragoza, and our colleagues at Baylor University. The views expressed herein are those of the authors and do not necessarily reflect the views of the National Bureau of Economic Research.

NBER working papers are circulated for discussion and comment purposes. They have not been peer-reviewed or been subject to the review by the NBER Board of Directors that accompanies official NBER publications.

(C) 2018 by Steven W. Bradley, James R. Garven, Wilson W. Law, and James E. West. All rights reserved. Short sections of text, not to exceed two paragraphs, may be quoted without explicit permission provided that full credit, including $\odot$ notice, is given to the source. 
The Impact of Chief Diversity Officers on Diverse Faculty Hiring

Steven W. Bradley, James R. Garven, Wilson W. Law, and James E. West

NBER Working Paper No. 24969

August 2018

JEL No. I23,I28,J78

\section{$\underline{\text { ABSTRACT }}$}

As the American college student population has become more diverse, the goal of hiring a more diverse faculty has received increased attention in higher education. A signal of institutional commitment to faculty diversity often includes the hiring of an executive level chief diversity officer (CDO). To examine the effects of a CDO in a broad panel data context, we combine unique data on the initial hiring of a CDO with publicly available faculty and administrator hiring data by race and ethnicity from 2001 to 2016 for four-year or higher U.S. universities categorized as Carnegie R1, R2, or M1 institutions with student populations of 4,000 or more. We are unable to find significant statistical evidence that preexisting growth in diversity for underrepresented racial/ethnic minority groups is affected by the hiring of an executive level diversity officer for new tenure and non-tenure track hires, faculty hired with tenure, or for university administrator hires.

Steven W. Bradley

Baylor University

One Bear Place \#98011

Waco, TX 76798

steve_bradley@baylor.edu

James R. Garven

Baylor University

One Bear Place \#98004

Waco, TX 76798

James_Garven@baylor.edu
Wilson W. Law

Baylor University

One Bear Place \#98003

Waco, TX 76798

Wilson_Law@baylor.edu

James E. West

Department of Economics

Baylor University

One Bear Place \#98003

Waco, TX 76798

and NBER

j_west@baylor.edu

A data appendix is available at http://www.nber.org/data-appendix/w24969 


\title{
The Impact of Chief Diversity Officers on Diverse Faculty Hiring *
}

\author{
Steven W. Bradley James R. Garven Wilson W. Law James E. West \\ Baylor University Baylor University Baylor University Baylor University \\ and NBER
}

August 18, 2018

\begin{abstract}
As the American college student population has become more diverse, the goal of hiring a more diverse faculty has received increased attention in higher education. A signal of institutional commitment to faculty diversity often includes the hiring of an executive level chief diversity officer (CDO). To examine the effects of a CDO in a broad panel data context, we combine unique data on the initial hiring of a CDO with publicly available faculty and administrator hiring data by race and ethnicity from 2001 to 2016 for four-year or higher U.S. universities categorized as Carnegie R1, R2, or M1 institutions with student populations of 4,000 or more. We are unable to find significant statistical evidence that preexisting growth in diversity for underrepresented racial/ethnic minority groups is affected by the hiring of an executive level diversity officer for new tenure and non-tenure track hires, faculty hired with tenure, or for university administrator hires. JEL Codes I23, I28, J78
\end{abstract}

\section{Introduction}

The issue of race and diversity on campus has been a central educational research and policy concern of universities for decades (Dee, 2005; Hurtado, Clayton-Pedersen, Allen, and Milem, 1998). Following President Lyndon Johnson's 1965 equal employment opportunity executive order (Johnson,

*Thanks to the Baugh Center for Free Enterprise, H. Bradley, C. Brown, E. Corey, Y. Liu, J. Meer, C. North, K. Renois, I. Udoetok, S. Zaragoza, and our colleagues at Baylor University. 
1965) affecting hiring practices of federal contractors, American universities quickly and voluntarily enacted similar affirmative action policies to increase the diversity of student populations (Arcidiacono and Lovenheim, 2016). However, changes in the diversity of faculty has proceeded at a slower pace. With faculties less diverse than their student bodies, universities have sought programs and policies designed to better increase faculty diversity. Advocates for greater diversity have argued that a higher-profile executive-level Chief Diversity Officer, preferably one who reports directly to the university president, can more effectively promote and encourage diversity at the highest level of university governance compared with lower level diversity-focused offices and organizations such as multicultural and diversity centers (Wilson, 2013). The movement to hire CDOs is gaining momentum. We find that in the 2016 academic year, more than two-thirds of the major U.S. Universities we study had a CDO in place.

In a university with shared governance, it is not immediately clear how much influence an executive level CDO can exert upon faculty hiring decisions made by individual departments. Yet increasing faculty diversity appears to enjoy broad support within academe. A 2017 survey found that $64 \%$ of provosts at Doctoral granting state universities and $53 \%$ of provosts overall agree or strongly agree that "Most academic departments at my institution place a high value on diversity in the hiring process" while $8 \%$ of Doctoral state university provosts disagree ( $0 \%$ strongly disagree) and $15 \%$ of all provosts disagree or strongly disagree (Jaschik and Lederman, 2017). University cultures also value academic freedom and local autonomy. Yet the number of new PhDs who are members of an underrepresented minority group vary widely by academic discipline. Despite widespread desire to increase faculty diversity, it simply may not be possible to rapidly increase faculty diversity given the pool of available faculty candidates.

The purpose of this paper is to present a first look at how the hiring of a CDO has affected the diversity of faculty and administrator hiring in four-year and above degree-granting American universities with 4,000 or more students from the 2001 through 2016 academic hiring cycles. To do so, we supplement publicly available data from the U.S. Department of Education Integrated Postsecondary Education Data System (IPEDS) with data we have gathered on the presence of an executive-level CDO. We are unable to find statistically significant evidence that diversity hiring patterns of faculty and administrators from universities with a CDO present differ from other 
universities in our sample which had not hired a CDO by the conclusion of the 2016 academic hiring cycle, or differ from patterns which existed in those same universities prior to hiring a CDO.

In the following sections, we discuss the emergence of the executive level diversity officer position, common roles of the position and the theoretical connection between faculty diversity and student diversity. We then document our data collection process and public IPEDS data used, followed by our methods, results, and discussion of our findings that may offer avenues for future research.

\section{Background and Literature Review}

\subsection{Diversity and the Role of Chief Diversity Officers}

Equal Employment Opportunity (EEO) offices have been a staple of the workplace since the passage of the Civil Rights Act of 1964, Title VII in 1964, and more recently the Americans with Disabilities Act in 1990. However, EEO and other multicultural and diversity offices were typically not executive-level offices within universities, but were located at the departmental level or as a division of student services.

A more recent trend is the hiring of executive level officers to coordinate various diversity initiatives on campus. Advocates for the establishment of a Chief Diversity Officer argue that a CDO must be an executive-level position and preferably one that reports directly to the president to enhance their effectiveness (Wilson, 2013). Damon Williams, founder of the Center for Strategic Diversity Leadership and Social Innovation and Katrina Wade-Golden, Deputy CDO and Director of Implementation for the Office of Diversity, Equity, and Inclusion, both at the University of Michigan, contrast the CDO with earlier positions:

What distinguishes the current executive diversity officer from its historical predecessors is the functional definition of diversity as a resource that can be leveraged to enhance the learning of all students and is fundamental to institutional excellence, in addition to its historic definition as the presence of individuals that differ by race, gender, or some other social identity characteristic. ... Given complexities like infusing diversity into the curriculum, enhancing the compositional diversity profile of students, faculty, and staff, and developing policies designed to improve the campus climate, the challenge of diversity is beyond the capabilities of any one individual, division, or team. Hence, chief diversity officers serve as powerful integrating forces for diversity issues, collaborating 
and working through the lateral networks of the institution no matter how large or small their staffs (Williams and Wade-Golden, 2007).

Recent work notes the growth in the diversity of $\mathrm{PhD}$ candidates and suggests that universities may not place enough emphasis on hiring underrepresented faculty (Smith, Turner, OseiKofi, and Richards, 2004). Data collected from the National Science Foundation's 2016 Survey of Earned Doctorates report (National Science Foundation, 2018, Table 12) indicates that the growth of PhDs awarded to members of underrepresented minorities exceeds the overall growth rate of PhDs awarded to U.S. citizens and permanent residents. Four socioeconomic trends have been offered to explain this push contributing for greater diversity in higher education (Williams and Clowney, 2007): 1) legal and political dynamics, 2) changing demographics, 3) the rise of a postindustrial knowledge economy, and 4) persistent societal inequities. Within the university setting, diversity may improve the individual well-being of members by increasing the likelihood that each person finds others with a similar background and common interests. It also offers opportunities for learning from individual or group differences that improve understanding in an increasingly globalized work environment. Business team diversity fosters more innovative ideas (Van Knippenberg and Schippers, 2007; Ruef, 2002) which would also apply to university research teams and classroom groups.

\subsection{Chief Diversity Officers, Faculty Hires, and Student Outcomes}

The recruitment and retention of underrepresented faculty are considered a key priority facilitated by CDOs to meet changing student demographics. The logic is that positive educational outcomes will result from congruency of student and professor race/ethnicity, thereby reducing achievement gaps for minority students (Campbell and Campbell, 1997). The most frequently cited benefits of this race/ethnicity matching hypothesis include greater engagement/retention, improved classroom discussion and better preparation for the real world (Maruyama, Moreno, Gudeman, and Marin, 2000). There are several theories seeking to explain why and how educational outcomes are associated with faculty-student gender or race/ethnicity congruency. Role model theories suggest increased student motivation through (1) behavioral modeling of how to perform a skill or achieve a goal; (2) showing that the skill or goal is possible; and (3) articulating that the goal is desirable 
and worth the effort (Almquist and Angrist, 1971; Basow and Howe, 1980; Morgenroth, Ryan, and Peters, 2015). The Pygmalion or Rosenthal Effect is a phenomenon where demographic similarities can positively influence faculty and student communication leading to higher expectations for enhanced performance (Rosenthal, Jacobson, et al., 1968). Stereotype theories suggest that a faculty member of a different gender and/or race may have an effect on student outcomes through negative stereotypes (Leslie, Cimpian, Meyer, and Freeland, 2015; Steele and Aronson, 1995). Faculty diversity and student outcomes as a research topic has been studied by scholars in multiple fields with mixed findings. ${ }^{1}$

A weakness of many of the earlier studies is an inability to credibly control for the likelihood of self-selection. For example, if female students are able to select which section of a large introductory course to enroll in, and higher achieving/more motivated female students specifically seek out female professors whereas lower achieving/less motivated female students must enroll in sections taught by male professors, it would not be statistically possible to separate preexisting ability and/or motivation from any gender-based professor effects upon student achievement.

Several recent studies use research designs and data which overcome some of these earlier methodological weaknesses. Carrell, Page, and West (2010) use data on the random assignment of students and professors into classrooms to investigate the effects of professor gender on student achievement at the U.S. Air Force Academy finding that in mandatory introductory STEM coursework, the achievement of female students increases when they are randomly assigned to female faculty members. In a second Academy study, Kofoed and McGovney (2017) examine the effects of randomly assigned mentors on career choices at the U.S. Military Academy. Students must choose from a small number of military specialties for their careers upon graduation. All students are more likely to choose the specialty of their military commander, but the study finds underrepresented minority students are additionally likely to choose the military specialty of their commanding officer if that commander is of the same racial/ethnic group.

A third study uses data from De Anza College, a large community college in the San Francisco Bay area. Fairlie, Hoffmann, and Oreopoulos (2014) address issues of self-selection by focusing

\footnotetext{
${ }^{1}$ See Bettinger and Long (2005), Buchmann, DiPrete, and McDaniel (2008), Canes and Rosen (1995), Dee (2004), Dee (2005), Ehrenberg, Goldhaber, and Brewer (1995), Hoffmann and Oreopoulos (2009), Neugebauer, Helbig, and Landmann (2010) Neumark and Gardecki (1998), and others.
} 
analysis on lower-achieving students with lower registration priority, and consequently, a more limited selection of faculty instructors. The findings show that underrepresented minority students are 1.2-2.8 percent more likely to pass classes, 2.0-2.9 percent less likely to drop out of classes, and 2.4-3.2 percent more likely to get a grade of B or higher in classes with underrepresented minority instructors. These represent modest, but statistically significant reductions in achievement gaps relative to majority groups ( $20 \%$ to $50 \%$ of the total gap). Subsequent course selection, retention, and degree completion of minority students are also positively influenced when matched with a minority faculty member.

In contrast to these positive findings, other studies also addressing selection effects at the secondary level (Dee, 2007; Neugebauer, Helbig, and Landmann, 2010; Helbig, 2012) and postsecondary level (Price, 2010) find either mixed results or no significance for teacher-student gender or race/ethnicity congruity on student performance. For example, in a study by Cho (2012) of 15 OCED countries using multi-wave TIMSS data that allows for student fixed effects estimation, there was no effect of teacher gender on student math performance outcomes. Another study finds overall positive effects of mentoring regardless of race or gender (Kim and Sax, 2009).

The nascent academic literature addressing CDOs often discusses the experiences and effects of CDOs through case studies from a handful of interviews with current CDOs (Parker, 2015; Wilson, 2013). Wilson (2013) states that the effectiveness of CDOs remains unknown. Therefore, whether CDOs influence the hiring of diverse faculty premised on the association with minority student outcomes is important to investigate. To the best of our knowledge, our study is the first largescale statistical analysis of the effects of a university CDO position on the diversity of faculty and administrator hiring.

\section{Data}

A critical initial decision in our analysis involves selecting which institutions to include in our sample. We prefer inclusion of the broadest sample of U.S. universities possible, but limit the dataset to institutions that are broadly comparable to one another in their selection of new faculty from the same pool of applicants. We include universities located in the United States which are 
classified as Carnegie R1 doctorate-granting universities with highest research activity, Carnegie R2 doctorate-granting universities with higher research activity and Carnegie M1 with larger master's degree-granting activity. Because our interest is the CDO position and the proportion of diversity hires, we limit our sample to R1, R2, and M1 universities with an enrollment of 4,000 or more undergraduates on the assumption that they are large enough to have regular hiring of new faculty and administrators and sample from 2001 through the 2016 academic year.

A wide variety of demographic, hiring, financial, and institutional characteristics are publicly available for this set of universities in the Integrated Postsecondary Education Data System (IPEDS) at the National Center for Education Statistics. Universities, prior to 2016, were only required to complete IPEDS surveys in odd academic years regarding the race and gender of employees hired. The recent mandate by the U.S. Department of Education requires annual reporting, but a subset of institutions did choose to voluntarily report the race and gender of new employees hired in even academic years as well. Due to concerns that institutions which chose to voluntarily report may differ systematically from those which did not, we use in our regression analysis only data from the academic years in which reporting was mandatory.

IPEDS does not record whether a university has employed an executive level chief diversity officer. We were not able to locate other sources which had compiled such data and instead gathered our own. Our data on whether an executive level CDO was present is the result of a three-step process. We employed a web scraping company to initially determine the year in which an executive level CDO was first hired for the universities in our data set. Our search for the start date of an executive level diversity position included variations of the Chief Diversity Officer title at a Vice President or higher level of organizational management. ${ }^{2}$ To assess whether a university established an executive diversity officer and the year hired, we searched university web pages, press releases, news articles, LinkedIn, university organizational charts, and other publicly available material. A coauthor of this paper and a graduate research assistant subsequently and separately repeated this same process as a way to independently verify data accuracy and reliability. The 462 universities included in our data set and the year in which the first executive-level CDO was hired are listed in

\footnotetext{
${ }^{2}$ Examples include Associate Provost for Equity and Inclusion, Senior Executive Assistant to the President for Diversity, and Vice President for Inclusion, Diversity, and Equal Opportunity, etc.
} 
Appendix A.

To correct for the possibility that increased diversity affects the decision of whether to hire a $\mathrm{CDO}$, we employ the proportion of peer $\mathrm{R} 1$ institutions which have a $\mathrm{CDO}$ in place as an instrument for the presence of a CDO. We posit that institutions look to best practices and innovations of other R1 institutions. We found that decisions regarding a CDO at R1 institutions within 100 miles do not have as much explanatory power over a R1 institution as the decisions regarding a CDO of all R1 institutions (excluding self) nationwide. This is consistent with our understanding that the U.S. market for higher education is a national as opposed to a localized market (Hoxby, 2016). Likewise, we found that CDO hiring decisions of R2 and M1 institutions were more affected by the decisions of all R1 institutions than by either nearby or nationwide institutions with the same Carnegie classification, perhaps because the decisions of these institutions are affected more by aspirational behaviors than peer institutions. In light of this, we calculate our instrument, Peer R1 CDOs, measured as the proportion of other R1 institutions which have a CDO present in the current year.

For our primary measurement of diversity, we use the proportion of the total number of students, faculty, or administrators who are identified as being members of an underrepresented minority group in IPEDS as African-American, Hispanic, or Native American/Pacific Islander. To measure current institutional diversity, we report the proportion of current undergraduate students, faculty of all academic rank and tenure status, and administrators who are members of an underrepresented minority group.

IPEDS reports a vast amount of data on each university. We report only selected relevant statistics in the interest of brevity. These include the average inflation-adjusted 9-month Assistant Professor salary, in- and out-of-state tuition plus fees, the proportion of students who are in-state, and statistics on student financial aid and loans. In addition, we compute the percentage growth in applications for undergraduate admission. We believe each of these indicators may also influence the ability to attract students and faculty, particularly in institutions where budgets are primarily funded by undergraduate tuition and fees.

As a secondary specification for diversity, we use a Herfindahl-like index to measure total di- 
versity, defined to be

$$
\text { Diversity }_{i t}=1-\sum_{g \in \mathbb{G}} p_{i g t}^{2}
$$

where $\mathbb{G}$ is the set of all racial and ethnic groups, and $p_{i g t}$ is the proportion of persons in university $i$ of racial/ethnic group $g$ in time $t$. This index assumes a value of zero if all members are of a single racial/ethnic group and reaches its maximum when all racial/ethnic groups are evenly represented. It is equal to the probability that two randomly drawn individuals from a large population come from different races (Simpson, 1949; Hirschman, 1980).

Within our sample of academic institutions, we also account for the role played by Historically Black Colleges and Universities (HBCU). These universities, founded prior to 1964 with the intention of serving the African-American community, have very high percentages of underrepresented minorities in their student bodies, faculty, and staff by design. Until very recently, most have not employed a CDO. Although these institutions meet all of the criteria for inclusion in our sample, we analyze the sample with and without HBCU so as to better understand the influence of these institutions on our results.

Summary statistics are presented in Table 1. Means and standard deviations for the full sample are reported in column (1). Column (2) reports summary statistics gathered only in the years where reporting of the racial and ethnic composition of newly hired faculty and staff is mandatory. In columns (3), (4), and (5), the institutions reported in column (2) are separated into their respective Carnegie classifications. Finally, in column (6) we separate out HBCU. We note the much higher prevalence of CDOs among Carnegie R1 institutions than R2 and M1 institutions. The summary data indicate a much higher proportion of underrepresented minority students, faculty, and administrators and a lower proportion of CDOs present at HBCU institutions than in the sample as a whole.

\subsection{Graphical Analysis}

The time period 2001-2016 has been one of substantial change in U.S. universities regarding issues of diversity and inclusion. To better illustrate dynamics within our data, we illustrate changes in demographic hiring practices related to the CDO position in Figure 2, and by specific academic 
position levels in Figure 1. For both figures, we omit HBCU due to the unique mission and demographics of these institutions. Figure 1a illustrates the rate at which universities in our sample have hired an executive level diversity officer over time. The proportion has steadily increased from 5.4 percent in 2001 to 67.6 percent in $2016 .{ }^{3}$ The remaining panels of Figure 1 illustrate trends by CDO presence for underrepresented (b) students, (c) faculty and (d) administrators in years for which demographic reporting was mandatory. The proportion of underrepresented minority students, faculty, and administrators illustrated in Figure 1b to 1d increased from 2001 through 2016 for universities with and without a CDO presence.

Perhaps surprisingly, the proportions for underrepresented groups has been consistently higher in universities without a CDO than with a CDO present over this time period. This finding may be a consequence, at least in part, of the changing composition of these groups. ${ }^{4}$ For underrepresented students (Figure 1b), the average gap by CDO position presence increased from 4.9 percent in 2001 to 8.5 percent in 2016. Figure 1c indicates the university proportion of underrepresented faculty by CDO presence, differed by only 0.4 percent in 2001, but that gap increased to 3.3 percent by 2016 . Likewise, the gap in the proportion of underrepresented administrators by CDO position presence grew from 3.8 percent in 2001 to 6.3 percent in 2016. Figures 1e and 1f are analogous to 1c and 1d, but with categories which do not change through time. Figures 1e and 1f contrast faculty and administrator diversity in universities which established an initial CDO in 2005 or earlier, defined as Early CDO, with universities which had not established a CDO by 2016.

Figure 2 illustrates more specific diversity hiring trends by CDO presence for (a) non-tenure track faculty, (b) tenure-track faculty, (c) tenured faculty, and (d) administrators along with the total number of corresponding hires for each category in Figure 2 panels e to h. We note the adverse effects of the Great Recession on overall hiring in 2007-2008 along with the remarkable stability of the proportion of diversity hires by CDO presence, given the underlying volatility in the academic job market. The post-recession hiring increases again across academic categories (Figure 2e to $2 \mathrm{~h}$ ) while the trend for the proportion of diversity hires by presence of CDO position continues through

\footnotetext{
${ }^{3}$ For the universities in our sample, in only one case was an existing CDO position eliminated. At the Provost's request, the CDO's duties were assumed by the Provost at this university.

${ }^{4} \mathrm{As}$ an example, if universities were rank ordered from least diverse to most diverse, for a given year, hiring a $\mathrm{CDO}$ at the least representative institutions will increase the average of both groups over time.
} 
2016 (Figure 2a to 2d), with the proportion of diverse hires typically lower in a given year with a CDO compared to campuses without the position

\subsection{Supply of New PhDs}

A comprehensive analysis of the academic job market and trends in diversity would require detailed data on both the supply and demand of academic job market candidates. IPEDS regrettably does not report data on academic job market applicants by university. However, the National Science Foundation (NSF) does collect data on the number of PhDs awarded annually by academic field and subfield by race and ethnic group. Table 2 contains a tabulation of earned PhDs awarded by U.S. universities to citizens and permanent residents in the 2016 academic year for all fields (bolded) and selected subfields within these fields (indented) by race and ethnic group. The final column of Table 2 reports PhDs awarded for members of underrepresented minority groups, which is a sum of the second, third, and fourth columns.

In 2016, 5,043 members of an underrepresented minority group earned a $\mathrm{PhD}$ out of a total of 35,719 PhDs earned for U.S. citizens or permanent residents, or $14.1 \%$ of the total. The NSF survey reports that in 2016, 48.5\% of U.S. citizens or permanent residents earning their $\mathrm{PhD}$ with definite employment plans at the time of the survey had secured jobs in academia. The proportion of underrepresented minorities with academic employment plans was comparable. ${ }^{5}$ In 2016, diverse hires were $11.6 \%$ of tenure-track faculty members in our sample (including Historically Black Colleges and Universities), and $13.7 \%$ of non-tenured faculty members. There is substantial variation in the proportion of earned $\mathrm{PhDs}$ by field for total underrepresented minorities, from a low of $7.9 \%$ in Physical Sciences and Earth Sciences to a high of $23.1 \%$ in Education. Variation by subfield is even more substantial with the proportion of PhDs earned by minorities as high as $40 \%$ for Latin American History and $38.2 \%$ for Area \& Ethnic \& Cultural \& Gender Studies, to a low of $6.4 \%$ in Physics and Astronomy and 9.6\% in Economics. Awarded PhDs in certain subfields of engineering not shown are even less diverse.

Unfortunately, the IPEDS data on faculty hiring by race is not disaggregated by academic

\footnotetext{
${ }^{5}$ The proportion of American Indian or Alaskan Natives was unreported due to small sample size and confidentiality. $47.3 \%$ of African Americans and $48.9 .8 \%$ of Hispanic and Latino employed PhDs had secured academic employment (National Science Foundation, 2018, Table 47).
} 
discipline. However, we infer from Table 2 that a university wishing to enhance the diversity of its faculty may be limited in the extent it can do so by the limited availability of PhDs in some academic disciplines.

\section{Methods and Results}

Although the primary focus of our paper is an examination of a CDO position hire to changes in faculty diversity, it is possible that the establishment of a CDO is driven, instead, by a response to growing campus diversity among students. In a 2017 survey conducted by Inside Higher Ed (Jaschik and Lederman, 2017), 51 percent of respondent provosts from doctoral-granting public universities responded in the affirmative to the following question: "Either because of the protests, or because of prior/subsequent commitments, does your college currently have a target for increasing the number or percentage of minority faculty members you employ by a certain date? " To better understand directions of causality, we implement a Granger Causality Test between the initial establishment of CDO and changes in student, faculty, and administrator hiring diversity, and growth in student applications for undergraduate admissions.

\subsection{Granger Causality}

Our dataset includes the number and demographic characteristics of incoming students, and new faculty and administrator hires. We first examine our data for empirical evidence of whether the establishment of a CDO is in response to changes in diversity, and whether diversity changes in response to the establishment of a CDO. The richness of our data set allows us to decompose changes in diversity into changes in student, faculty, and administrator diversity. In addition to changes in diversity, we also include changes in annual applications for admissions. ${ }^{6}$ Equations 2-5 implement a standard Granger Causality Test on these related variables where $\triangle C D O_{i t}$ represents whether a CDO was established by university $i$ between years $t-1$ and $t . \Delta U_{i t}^{s}$ is the change in the proportion of underrepresented students from year $t-1$ to year $t . \Delta U_{i t}^{f}$ is the change in

\footnotetext{
${ }^{6}$ We include this variable to account for the possibility that a university may establish a CDO position in response to adverse publicity and a corresponding drop in applications, or the possibility of an increase in applications due to the establishment of a CDO.
} 
underrepresented faculty, and $\Delta_{i t}^{a}$ is the change in underrepresented administrators. $\Delta A_{i t}$ is the change in the number of applications for admission.

$$
\begin{aligned}
\Delta C D O_{i t} & =\beta_{10, i}+\sum_{j=1}^{5}\left(\beta_{11, j} \Delta C D O_{i t-j}+\beta_{12, j} \Delta U_{i t-j}^{s}+\beta_{13, j} \Delta U_{i t-j}^{f}+\beta_{14, j} \Delta U_{i t-j}^{a}+\beta_{15, j} \Delta A_{i t-j}\right)+\varepsilon_{1 i t} \\
\Delta U_{i t}^{s} & =\beta_{20, i}+\sum_{j=1}^{5}\left(\beta_{21, j} \Delta C D O_{i t-j}+\beta_{22, j} \Delta U_{i t-j}^{s}+\beta_{23, j} \Delta U_{i t-j}^{f}+\beta_{24, j} \Delta U_{i t-j}^{a}+\beta_{25, j} \Delta A_{i t-j}\right)+\varepsilon_{2 i t} \\
\Delta U_{i t}^{f} & =\beta_{30, i}+\sum_{j=1}^{5}\left(\beta_{31, j} \Delta C D O_{i t-j}+\beta_{32, j} \Delta U_{i t-j}^{s}+\beta_{33, j} \Delta U_{i t-j}^{f}+\beta_{34, j} \Delta U_{i t-j}^{a}+\beta_{35, j} \Delta A_{i t-j}\right)+\varepsilon_{3 i t} \\
\Delta U_{i t}^{a} & =\beta_{40, i}+\sum_{j=1}^{5}\left(\beta_{41, j} \Delta C D O_{i t-j}+\beta_{42, j} \Delta U_{i t-j}^{s}+\beta_{43, j} \Delta U_{i t-j}^{f}+\beta_{44, j} \Delta U_{i t-j}^{a}+\beta_{45, j} \Delta A_{i t-j}\right)+\varepsilon_{4 i t} \\
\Delta A_{i t} & =\beta_{50, i}+\sum_{j=1}^{5}\left(\beta_{51, j} \Delta C D O_{i t-j}+\beta_{52, j} \Delta U_{i t-j}^{s}+\beta_{53, j} \Delta U_{i t-j}^{f}+\beta_{54, j} \Delta U_{i t-j}^{a}+\beta_{55, j} \Delta A_{i t-j}\right)+\varepsilon_{5 i t}
\end{aligned}
$$

Table 3 reports the results from a Granger causality test with specifications in columns 2 through 6 in Table 2 matching equations (2) through (6) above. In Panel A of Table 2, we present our analysis on the full sample of universities, and in Panel B we omit HBCU due to their unique nature as mentioned previously. We report the F-statistics for the joint significance of each group of explanatory variables in Table 3, with $p$-values in square brackets underneath. In each specification, we estimate the first through fifth lags of each variable, but do not report an F-statistic for lags of the dependent variable, since this lacks any economic meaning. ${ }^{7}$ The proportion of underrepresented students is reported on an annual basis, but the reporting of faculty and administrator demographics as well as applications are not mandatory in even calendar years. To enable the use of all years in the estimation of Equations 2-6, we impute unreported values linearly. ${ }^{8}$

Comparing Table 3 Panels A and B, we note the different patterns and magnitudes of significance as evidence that HBCU are distinctly diverse regarding students, faculty, and administrators, while largely absent of a CDO presence due to the historic mandate of these institutions. This suggests Panel B is a more appropriate specification for understanding the effects of a CDO upon institutions with lower proportions of diverse faculty, students, and administrators.

\footnotetext{
${ }^{7}$ Whether a university has a CDO present in years $t-5$ through $t-1$ has high explanatory power over whether a CDO is present in year $t$, but this is not of any interest in examining cross-variable correlations.

${ }^{8}$ Missing values are imputed by taking a time-weighted average of preceding and following observations. While not ideal, we rely upon the assumption that diversity measures do not rapidly change over time based on trends in the dataset.
} 
We focus interest primarily on the first column of Table 3, labeled (2), which tests for the effect of changes in diversity and university applications that are correlated with the establishment of a new CDO, and the first row of parameter estimates in Panel B, which represent the effect of a new $\mathrm{CDO}$ on these measurements of diversity and applications. In our preferred Panel B, past changes in faculty diversity are not significantly correlated with the establishment of a new CDO. Past changes in administrator and student diversity are only marginally correlated with the establishment of a new CDO, while past changes in the growth of university applications are significantly correlated at the 5 percent level. Although F-statistics can only indicate the presence or absence of joint correlation but not the sign of the relationship, all unreported individual regression coefficients which are individually significant are negative. Negative coefficients indicate that recent admissions growth rates below the sample average are correlated with the initial establishment of an CDO. ${ }^{9}$ In contrast, there does not appear to be a significant correlation between either more rapidly increasing or decreasing diversity and the initial establishment of a CDO. From the first row of Panel B, with the initial establishment of a CDO within the past five years, we are unable to find any significant effects of the initial establishment of a CDO on faculty or administrator diversity or on university application growth. There is a marginal effect on the percentage of underrepresented students.

\subsection{Main Specifications}

An executive level CDO could affect the diversity of faculty and administrators both by encouraging the hiring of greater numbers of diverse candidates, and by better retaining current diverse faculty and administrators. The measurements of diversity used in the previous section, change in the proportion of diverse current faculty, administrators, or students, represents the sum of incoming and attrition effects. Ideally, we would like to analyze the effect of a CDO on both hiring and attrition. Although IPEDS reports very detailed data on hiring, the surveys did not inquire about attrition, and limitations of the data set limit our ability to carefully calculate attrition. ${ }^{10}$ Our data

\footnotetext{
${ }^{9}$ It is beyond the scope of this paper to establish why a university should see a sudden drop in applications. We note that adverse publicity is one possibility.

${ }^{10}$ IPEDS requires that universities report both new hires and existing faculty and administrators on a biannual basis. Because of this, it would not be possible to reliably estimate annual attrition.
} 
does enable us to estimate the effects of a CDO and other potential covariates on the proportion of new hires by an individual university who are members of an underrepresented minority group.

$$
U_{i t}^{h}=\beta_{0 i}+C D O_{i t-1}+\beta_{1} \Delta U_{i t-1}^{s}+\beta_{2} \Delta U_{i t-1}^{f}+\beta_{3} \Delta U_{i t-1}^{a}+\beta_{4} \Delta A_{i t-1}+\phi_{t}+\varepsilon_{i t}
$$

Where $U_{i t}^{h}$ represents the proportion of hires who are members of an underrepresented minority in university $i$ at year $t$. $C D O_{i t-1}$ is an indicator variable whether university $i$ had a CDO in place in year $t-1$. IPEDS defines a hire by the academic year in which they are added to the university payroll. If a faculty member is added to the university payroll in August of year $t$, the hiring process for this faculty member took place during the previous academic year, $t-1$. A CDO presence in the time period in which hiring decisions are made should have the largest potential effect on hires that begin the following year. $U^{s}, U^{f}$, and $U^{a}$ are the proportion of existing students, faculty, and administrators who are members of an underrepresented minority included as controls. The change in each of these variables is used as opposed to the total number out of concern that the total of each variable is growing over time as seen in Figures 1 and $2 .{ }^{11} \Delta A_{i t-1}$ is the growth in student applications to university $i$ in year $t-1$. $\beta_{0 i}$ and $\phi_{t}$ are university level and time fixed effects. By using a fixed effects specification, we do not attempt to explain differences in the diversity of hiring practices across universities, but examine how the diversity of hires in one particular year compares to the average of that same university over the sample period. Time fixed effects account for the changing annual diversity of job candidates. We estimate equation (7) for dependent variables of non-tenured faculty hires, tenure-track faculty hires, tenured faculty hires, administrator hires, and the change in graduate students. We include graduate students because the set of graduate students contains future faculty members and many graduate students are also classroom instructors. IPEDS does not collect data on incoming graduate students. We include the change in the proportion of underrepresented graduate students as an alternative.

We report OLS fixed effect estimates of Equation (7) in Table 4. As in Table 3, we report estimates using the full sample in Panel A and omit HBCU in Panel B. The Chief Diversity Officer (CDO) variable of interest is dummy variable coded 1 in years when a CDO is present and 0

\footnotetext{
${ }^{11}$ Since we only analyze data when reporting is mandatory, the change between adjacent observations in our data set represents biannual changes.
} 
otherwise. We interpret the coefficient as the effect of a CDO on diversity hiring relative to that same university in the absence of a CDO, controlling for the diversity of job candidates, changing diversity of existing students, faculty, and administrators, and the growth of student applications. We are unable to find any statistical effects of the presence of a CDO on the diversity of hires in the full sample. In Panel B with HBCU omitted, we find that the proportion of underrepresented tenured faculty hired in universities with a CDO present is 2.8 percentage points less diverse than in universities without a CDO at a 10 percent level of significance. We note that the largest and most significant effects are those of changes in the percent of underrepresented faculty on diverse tenure-track hires, and of changes in the percent of underrepresented administrators on diverse administrator hires. Although we believe that because of their historic mission, these correlations exist within $\mathrm{HBCU}$ institutions, we note that these correlations become larger when HBCU institutions are omitted in Panel B. In Column 2, Panel B, as the percentage of underrepresented faculty rose by 1 percentage point, the proportion of diverse tenure-track faculty hired increased by 1.096 percentage points. We find an equally significant but numerically smaller effect of existing administrator diversity on the proportion of diverse administrators hired. We interpret both of these coefficients as evidence of homophily - the tendency of individuals to associate, network, and bond with similar others (McPherson, Smith-Lovin, and Cook, 2001).

Table 3 presented statistical evidence that the decision to establish a Chief Diversity Officer is endogenous with respect to student and administrator diversity, and growth in applications. Other sources of unobserved endogeneity, such as a university desire to increase faculty and administrator diversity, are plausible and likely. (Jaschik and Lederman, 2017) If the decision to establish a CDO position is affected by the interaction between academics and administrators with those of peer and aspirant institutions, the proportion of peer and aspirant institutions with a CDO is a possible instrument. Although we found that the presence of a CDO at a Carnegie R1 institution is significantly affected by the proportion of peer R1 institutions with a CDO, the decision in R2 and M1 institutions were much more closely correlated with R1 universities than with peer R2 and M1 institutions. We interpret this as evidence that R2 and M1 institutions view R1 institutions as institutions that they aspire to become like, more so than institutions of the same Carnegie classification. In light of this, we use as our exogenous instrument the lagged proportion of peer 
R1 institutions with a CDO present for each of the R1, R2, and M1 institutions.

We present instrumental variables fixed effects estimates of Equation (7) in Table 5. For each regression estimate, we report the first stage $F$ statistic from excluding our exogenous instrument, Lagged Peer R1 CDOs. Our IV specifications do not suffer from weak instruments, as the smallest reported first stage $F$ statistic of 244.3. As in Table 4, the only specifications in which we find an effect of a CDO being present is in the proportion of diverse tenured faculty hired. With IV estimates, the effect of a CDO is now significant at a 5 percent level both in the full sample and with HBCU institutions omitted. In Panel B, the proportion of diverse tenured faculty hired was 5.6 percentage points lower with a CDO present than in the same institutions without a CDO.

\subsection{CDO Effect with Limited Supply of Diverse Candidates}

If in the market for academic positions of all types investigated in this paper were characterized by more institutions desiring to hire diverse candidates than diverse candidates on the job market, the possibility of a university increasing its diversity would be limited (Flaherty, 2015). It is possible under this scenario that a CDO would enable the employer to better compete against other universities without a CDO in the academic job market for scarce diverse candidates, even though the reported proportion of diverse candidates may see limited changes. To measure the success of a university in recruiting diverse hires relative to other institutions, we compute the proportion of total hires within a year that are underrepresented, $p_{t}$. Let university $i$ in year $t$

hire $N_{i t}$ positions, $n_{i t}$ of which are diverse. If each hire were interpreted as an opportunity to hire a diverse candidate with probability $p_{t}$, the probability of the observed outcome is distributed Binomial with probability density of

$$
P\left(n_{i t}, N_{i t}\right)=\frac{N_{i t} !}{n_{i t} !\left(N_{i t}-n_{i t}\right) !} p_{t}^{n_{i t}}\left(1-p_{t}\right)^{\left(N_{i t}-n_{i t}\right)}
$$

We use for our dependent variable in Tables 5 and 6 the cumulative distribution function $C D F\left(n_{i t}, N_{i t}\right)$, or the probability of hiring up to $n_{i t}$ diverse candidates out of $N_{i t}$ total hires. A larger value can be interpreted as a university that is more successful in hiring diverse candidates relative to peer institutions. 
In Table 6, we present OLS estimates of Equation (7) using the relative success of an institution in hiring diverse candidates as the dependent variable. In both Panels A and B, we are unable to find any effect of a CDO. We continue to find strong evidence of homophily, now in non-tenured, tenure-track, and administrator hires at the 1 percent level of significance. We find the same patterns of significance when correcting for the likely endogeneity of a CDO in Table 7 . We are unable to find evidence of a CDO effect relative to universities without a formal CDO position in the hiring of non-tenured, tenure-track, tenured faculty, or administrators.

To check for possible effects of a CDO on a broader measurement of diversity, we estimate Equation (7) using the diversity index defined in Equation (1). We report OLS estimates in Table 8 and IV estimates in Table 9. In Table 8, we are unable to find effects of a CDO in the overall diversity of hires within each of the four categories considered. However, we now observe homophily for the first time in tenured faculty hiring, although at a lower 5 percent level of significance in Panel B. Correcting for the likely endogeneity of a CDO in Table 9, we now find negative effects on the diversity index of tenured faculty hires at the 5 percent level.

\section{Discussion}

Universities are increasingly hiring executive level diversity administrators (CDOs) signaling a commitment to increased diversity. This study began with an overview of diversity trends among students and faculty in higher education and the logic of hiring a CDO. A key role of the executive

level position is to promote faculty diversity hiring to increase congruity between faculty-student gender and race/ethnicity. A key motive for better matching faculty and student on these characteristics is to enhance support for underrepresented students which, in turn, may lead to improvements in student satisfaction and performance. We empirically test whether this executive level administrative position significantly alters faculty diversity hiring practices beyond normal growth patterns of faculty diversity from 2001 to 2016 . Importantly, we are unable to find evidence that preexisting patterns in diversity hiring are altered by the hiring of an executive level diversity officer at the faculty or administration hiring level using a number of alternative specifications. We do find patterns of homophily for current faculty/administrator diversity and new hires. 
The trend for hiring executive level diversity officers (Figure 1a) began in the early 2000s. By 2016, approximately 65 percent of higher education institutions established a form of this executive position. Higher education student gender and race/ethnicity characteristics have also changed over the 15-year sample frame with the overall proportion of underrepresented students increasing from 0.189 in 2001, to 0.255 in 2016. Figure 1 b shows student diversity trends for institutions with and without a CDO in place. Diversity among faculty and administrators has also increased (Figures 1.c to 1.f), but at a slower rate than student diversity. For example, the overall proportion of underrepresented faculty was 0.089 in 2001 and 0.110 in 2016. In Figure 1, it is notable that universities without CDOs have higher proportions of minority faculty than those with a CDO. While a perceived lack of diversity relative to peer institutions could be used to justify hiring a CDO, the gap between the diversity of institutions with and without a CDO is greater in 2016 than in 2001. In Tables 6 and 7, we were unable to find evidence of a sustained advantage for diverse hiring relative to other institutions due to the presence of a CDO. It is possible this finding reflects the lack of authority the CDO has over hiring decisions. Hiring decisions are generally entrusted to departments given their expertise in the field. Cabinet-level officers might, in effect, have very little influence in decisions made at the department and college level. In the remainder of this section, we offer alternative possible explanations for our inability to find significant effects of a CDO on diversity hiring trends; and suggest potential avenues for future research.

\subsection{Limited Supply of Diverse PhD Job Candidates}

The dataset we analyze on the proportion of non-tenured, tenure-track, and tenured faculty and administrators who are members of an underrepresented minority group properly represents the outcome of a two-sided matching problem between universities and job market candidates. Detailed data on the preferences of institutions that are hiring, and detailed attributes and preferences of job market candidates are not available from IPEDS or other sources we can access. In our discussion of Table 2, we noted that in 2016, 14.1\% of earned PhDs awarded to U.S. citizens and permanent residents were to members of underrepresented minority groups. The supply of job candidates is further limited by approximately 50 percent of minority $\mathrm{PhD}$ recipients accepting employment outside the academic sector according to the 2016 NSF survey. We can also examine the distribution 
of $\mathrm{PhDs}$ earned by race in 2016 from Table 2. Evidence points toward a congregation by field and subfield for underrepresented minorities. For example, of the 2,360 degrees earned by Black candidates in 2016, 27\% were in education $(640 / 2,360)$ and $21 \%$ were in Psychology and Social Sciences $(495 / 2,360)$. For the subfield of Physics and Astronomy, there were less than 1\% $(23 / 2,360)$ of total PhDs obtained for the year by Black doctoral candidates with a similar trend of limited candidates reported in Economics (Bayer and Rouse, 2016). These disparities in the presence of underrepresented minority academic job market candidates across academic fields could contribute to underrepresentation in the aggregate. Further research is needed to determine whether this is the case.

\subsection{Recruitment and Retention Initiatives}

In the theory of a two-sided matching problem, members of each side determine a rank ordering of available options. As applied to the academic job market, candidates rank order potential employers, and hiring departments rank order potential candidates. A university hoping to make its faculty more diverse can boost its attractiveness to underrepresented candidates by offering higher salaries or reduced teaching loads. As an example, Yale University recently announced a five-year, $\$ 50$ million-dollar campaign to increase faculty diversity (Yale University, 2016). Carnegie Research Intensive (R1) universities as a group are characterized by greater financial resources devoted to research and larger endowments (Phillips, Lombardi, Abbey, and Craig, 2016), which should enable such institutions desiring to increase faculty diversity to make more attractive offers to diverse candidates. We present summary statistics in Table 1, Columns 3, 4, and 5 for Carnegie R1, R2, and M1 institutions respectively. Despite increased resources which could enable R1 institutions to make more financially attractive offers, these institutions as a group have less diverse faculty and administrators than R2 and M1 institutions. We interpret this as evidence that financial resources alone are not enough to increase faculty and administrator diversity. We were not able to find careful, scholarly analyses of diverse faculty turnover, but in online sources, advocates of diversity have suggested that reducing the turnover of diversity faculty may be a more effective path to increasing faculty diversity (Ann, 2016). Analysis of a survey of associate professors at 50 universities found non-monetary factors, such as quality relationships with colleagues, more 
important to workplace commitment than formal programs including diversity hiring initiatives (Mackey, 2017). Beginning in 2016, universities must report annually both current and new faculty and administrators by gender and racial/ethnic group. This will enable future researchers to impute annual attrition by racial and ethnic group and perform a detailed analysis of faculty turnover.

\subsection{Carnegie Classifications, Urbanization, and Geographic Regions}

The main specifications of our analysis included university level fixed effects to restrict our analysis to variation of underrepresented hiring within individual universities. A consequence of this is the inability to include explanatory variables which are time-invariant. For the 2016 academic year hiring cycle, we consider variation in diverse hiring by Carnegie classification, the degree of urbanization as recorded by IPEDS, and the U.S. Census region. Carnegie classification is of interest to test whether research intensity and the additional financial resources that accompany it are effective in successfully attracting underrepresented candidates. IPEDS records the degree of urbanization that a university is located in from a large city to a distant rural area. Additionally, we consider the four U.S. Census regions: Northeast, Midwest, South, and West. Results appear in Table 10. For each category of academic position we consider; non-tenured, tenure-track, tenured, and administrator, we present the proportion of positions where the academic hired was black, Hispanic, a native American, or an underrepresented minority, which is a sum of the previous categories. Column 1 presents proportions, and Columns 2 through 4 present an $F$-statistic testing equality of means across groups.

The $F$-test of significance for difference of mean underrepresented group hired by Carnegie category (R1, R2, or M1) is presented in Column 2. We are unable to find any significant difference for underrepresented minority groups in aggregate. Looking at individual racial/ethnic groups within underrepresented minority groups, we find marginally significant differences in the percentage of black tenure track faculty and black administrators hired. We also find highly significant evidence of differences across Carnegie categories for the percent of native administrators hired, though we note that in 2016, only 27 native administrators were hired nationwide. Interestingly, we find highly significant differences in the proportion of universities with a CDO in place by Carnegie category. Carnegie R1 institutions are substantially more likely to have a CDO in place in 2016 than R2 or 
M1 institutions.

Differences by urbanization are presented in Column 3. The percentage of black non-tenured faculty hired differs significantly by degree of urbanization. We find that the proportion of black non-tenured faculty hired is substantially greater in large cities and midsize cities than in suburban, towns, or rural areas. We find a similar concentration of Hispanic administrators in large urban areas. A sharply lower proportion of CDOs in place in Remote Towns causes the average proportions of CDOs in place by degree of urbanization to differ at a highly significant level.

We find substantial variation in diverse hiring by census region. For non-tenured faculty, the proportion of Black and Hispanic faculty hired have highly significant variation by census region. In the West, where the proportion of non-tenured faculty who are Hispanic is highest, the proportion of Black faculty is lowest. And in the South, where the proportion of Black faculty hired is dramatically higher, the proportion of Hispanic faculty hired is well below the national average. The proportion of underrepresented non-tenured faculty hired as a group is only marginally significant, due to offsetting regional variation by Black and Hispanic faculty hired. Hispanic tenure-track faculty are also heavily represented in the West, but we do not find significant regional variation by Black tenure-track faculty hired. Significant variation by census region also exists in administrator hiring. Interestingly, the proportion of universities with a CDO in place does not exhibit any significant regional variation.

IPEDS data on faculty hiring represents the dual coincidence of wants between job candidates and hiring institutions. As such, it is not possible with IPEDS data to identify whether the disparities by group in Table 10 are due to candidate preferences, institutional desires, or both. Additional work to understand the role of urbanization and geographic region on institutional diversity is needed.

\subsection{Public Choice}

Our discussion assumes the objective of universities in our sample is to increase the proportion of faculty and administrators who are members of an underrepresented group, subject to various constraints. Under this paradigm, senior administrators establish a CDO for the particular purpose of increasing the proportion of underrepresented members in the overall interests of the university. 
However, if a university hires a CDO to appease critics or to quell negative publicity with no intention of increasing diversity, then the lack of a significant effect on faculty diversity is less surprising. Under this scenario, even negative and significant effects of a CDO on diversity may be found, as we do in Table 5, Column 4. In our data, the proportion of diverse tenured faculty hired is $5.61 \%$ lower with an active CDO in place. Unfortunately, we do not have an identification strategy to parse out university motives for CDO hiring that would distinguish universities with strong intentions to increase diversity from those with placating motives. Our results do show an important finding with policy implications regardless of the cause for lack of CDO hiring efficacy. Future research may consider in greater detail why across a population of larger U.S. universities, no significant effect of CDO establishment is found on diversity hiring.

\section{Conclusion}

This study examines the effect of an executive-level CDO on the diversity of faculty and administrator hires for the set of 4-year or above degree-granting U.S. universities with 4,000 or more students from 2001 to 2016. Using a wide variety of robust specifications, we are unable to find significant evidence that the presence of an executive level CDO alters preexisting trends of increasing faculty and administrator diversity in the institutions we study. Our inability to identify a significant effect should not be interpreted as an argument that an effect does not exist. Given the importance of this topic to the academic community, much additional work remains to be done. We performed our analysis using data on the race and ethnicity of faculty and administrator positions at the institutional level. Data from the National Science Foundation by academic discipline and subdiscipline reveal large differences in the proportion of underrepresented persons earning a $\mathrm{PhD}$ by academic field. Although important progress has been made in increasing faculty and administrator diversity from 2001 to 2016, we believe more work must be done to better understand barriers to increased diversity, and how they might be best addressed. 


\section{References}

Almquist, E. M., And S. S. Angrist (1971): "Role model influences on college women's career aspirations," Merrill-Palmer Quarterly of Behavior and Development, 17(3), 263-279.

Ann, K. (2016): "For a Diverse Faculty, Start With Retention," .

Arcidiacono, P., And M. Lovenheim (2016): "Affirmative Action and the Quality-Fit Tradeoff," Journal of Economic Literature, 54(1), 3-51.

Basow, S. A., And K. G. Howe (1980): "Role-Model Influence: Effects of Sex and Sex-Role Attitude in College Students," Psychology of Women Quarterly, 4(4), 558-572.

Bayer, A., And C. E. Rouse (2016): "Diversity in the economics profession: A new attack on an old problem," Journal of Economic Perspectives, 30(4), 221-42.

Bettinger, E., And B. T. Long (2005): "Do Faculty Serve as Role Models? The Impact of Instructor Gender on Female Students," American Economic Review, 95(2), 152-157.

Buchmann, C., T. A. DiPrete, and A. McDaniel (2008): "Gender Inequalities in Education," Annual Review of Sociology, 34, 319-337.

Campbell, T. A., and D. E. Campbell (1997): "Faculty/student mentor program: Effects on academic performance and retention," Research in Higher Education, 38(6), 727-742.

Canes, B., And H. Rosen (1995): "Following in Her Footsteps? Faculty Gender Composition and Women's Choices of College Majors," Industrial and Labor Relations Review, 48(3), 486-504.

Carrell, S. E., M. E. Page, and J. E. West (2010): "Sex and Science: How Professor Gender Perpetuates the Gender Gap," Quarterly Journal of Economics, 125(3), 1101-1144.

CHO, I. (2012): "The effect of teacher-student gender matching: Evidence from OECD countries," Economics of Education Review, 31(3), 54-67.

Dee, T. S. (2004): "Teachers, Race, and Student Achievement in a Randomized Experiment," Review of Economics and Statistics, 86(1), 195-210. 
_ (2005): “A Teacher Like Me: Does Race, Ethnicity, or Gender Matter?," American Economic Review, 95(2), 158-165.

(2007): "Teachers and the Gender Gaps in Student Achievement," Journal of Human Resources, 42(3), 528-554.

Ehrenberg, R. G., D. D. Goldhaber, and D. J. Brewer (1995): "Do Teachers' Race, Gender, and Ethnicity Matter? Evidence from the National Educational Longitudinal Study of 1988," Industrial and Labor Relations Review, 48(3), 547-561.

Fairlie, R. W., F. Hoffmann, and P. Oreopoulos (2014): "A Community College Instructor Like Me: Race and Ethnicity Interactions in the Classroom," The American Economic Review, 104(8), 2567-2591.

Flaherty, C. (2015): "Student Activists Want More Black Faculty Members. But How Realistic Are Some of Their Goals?," https://www.insidehighered.com/news/2015/11/30/studentactivists-want-more-black-faculty-members-how-realistic-are-some-their-goals.

Helbig, M. (2012): "Boys Do Not Benefit from Male Teachers in Their Reading and Mathematics Skills: Empirical Evidence from 21 European Union and OECD Countries," British Journal of Sociology of Education, 33(5), 661-677.

Hirschman, A. O. (1980): National Power and the Structure of Foreign Trade, vol. 105. Univ of California Press.

Hoffmann, F., and P. Oreopoulos (2009): "A Professor Like Me: The Influence of Instructor Gender on College Achievement," Journal of Human Resources, 44(2), 479-494.

Hoxby, C. (2016): "The Dramatic Economics of the U.S. Market for Higher Education," 2016 Martin S. Feldstein Lecture presented at the 2016 NBER Summer Institute.

Hurtado, S., A. R. Clayton-Pedersen, W. R. Allen, and J. F. Milem (1998): "Enhancing Campus Climates for Racial/Ethnic Diversity: Educational Policy and Practice," The Review of Higher Education, 21(3), 279-302. 
Jaschik, S., And D. Lederman (2017): "Survey of College and University Chief Academic Officers," https://goo.gl/3F1YYf, Inside Higher Ed.

Johnson, L. B. (1965): "Equal Employment Opportunity," U.S. Presidential Executive Order 11246, Federal Register.

KIm, Y. K., And L. J. SAx (2009): "Student-Faculty Interaction in Research Universities: Differences by Student Gender, Race, Social Class, and First-Generation Status," Research in Higher Education, 50(5), 437-459.

Kofoed, M. S., And E. McGovney (2017): "The Effect of Same-Gender and Same-Race Role Models on Occupation Choice: Evidence from Randomly Assigned Mentors at West Point," Journal of Human Resources, pp. 0416-7838r1.

Leslie, S.-J., A. Cimpian, M. Meyer, and E. Freeland (2015): "Expectations of Brilliance Underlie Gender Distributions Across Academic Disciplines," Science, 347(6219), 262-265.

MACKey, J. (2017): "How to Sustain Faculty Diversity," .

Maruyama, G., J. F. Moreno, R. H. Gudeman, and P. Marin (2000): "Does Diversity Make a Difference? Three Research Studies on Diversity in College Classrooms," https://files.eric.ed.gov/fulltext/ED444409.pdf, ERIC.

McPherson, M., L. Smith-Lovin, And J. M. Cook (2001): "Birds of a Feather: Homophily in Social Networks," Annual Review of Sociology, 27(1), 415-444.

Morgenroth, T., M. K. Ryan, and K. Peters (2015): "The Motivational Theory of Role Modeling: How Role Models Influence Role Aspirants' Goals," Review of General Psychology, $19(4), 465$.

National Science Foundation (2018): "Doctorate Recipients from U.S. Universities: 2016," Report, National Center for Science and Engineering Statistics.

Neugebauer, M., M. Helbig, and A. Landmann (2010): "Unmasking the Myth of the SameSex Teacher Advantage," European Sociological Review, 27(5), 669-689. 
Neumark, D., and R. Gardecki (1998): "Women Helping Women? Role Model and Mentoring Effects on Female Ph.D. Students in Economics," Journal of Human Resources, 33(1), 220-46.

PARker, E. T. (2015): "Exploring the Establishment of the Office of the Chief Diversity Officer in Higher Education: A Multisite Case Study," http://ir.uiowa.edu/etd/1995/, Ph.D. thesis, University of Iowa.

Phillips, E. C., J. V. Lombardi, C. W. Abbey, and D. D. Craig (2016): "The Top American Research Universities," Annual report, The Center for Measuring University Performance.

PRICE, J. (2010): "The Effect of Instructor Race and Gender on Student Persistence in STEM Fields," Economics of Education Review, 29(6), 901-910.

Rosenthal, R., L. Jacobson, et Al. (1968): Pygmalion in the Classroom: Teacher Expectation and Pupils' Intellectual Development. Holt, Rinehart and Winston, New York.

Ruef, M. (2002): "Strong Ties, Weak Ties and Islands: Structural and Cultural Predictors of Organizational Innovation," Industrial and Corporate Change, 11(3), 427-449.

Simpson, E. H. (1949): "Measurement of Diversity," Nature, 163(4148), 688.

Smith, D. G., C. S. V. Turner, N. Osei-Kofi, and S. Richards (2004): "Interrupting the Usual: Successful Strategies for Hiring Diverse Faculty," The Journal of Higher Education, 75(2), $133-160$.

Steele, C. M., And J. Aronson (1995): "Stereotype Threat and the Intellectual Test Performance of African Americans," Journal of Personality and Social Psychology, 69(5), 797.

Van Knippenberg, D., and M. C. Schippers (2007): "Work Group Diversity," Annu. Rev. Psychol., 58, 515-541.

Williams, D., And K. Wade-Golden (2007): "The chief diversity officer," CUPA HR JOURNAL, 58(1), 38 .

Williams, D. A., And C. Clowney (2007): "Strategic Planning for Diversity and Organizational Change," Effective Practices for Academic Leaders, 2(3), 1-16. 
Wilson, J. L. (2013): "Emerging Trend: The Chief Diversity Officer Phenomenon Within Higher Education," The Journal of Negro Education, 82(4), 433-445.

YAle University (2016): "Yale is building on faculty diversity and excellence through $\$ 50$ million initiative," https://news.yale.edu/2016/09/07/yale-building-faculty-diversity-andexcellence-through-50-million-initiative. 
Figure 1: Dynamics of Diversity in Existing Groups

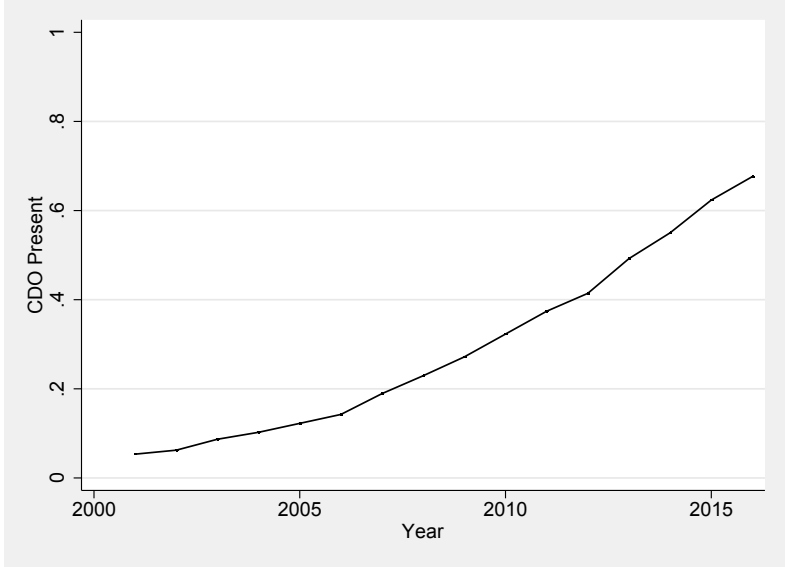

(a) Universities with a CDO Present

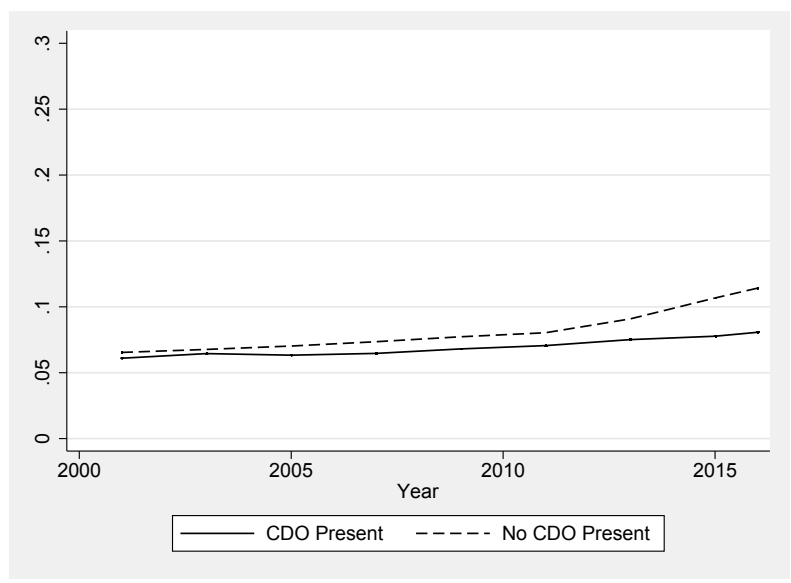

(c) Underrepresented Faculty by CDO

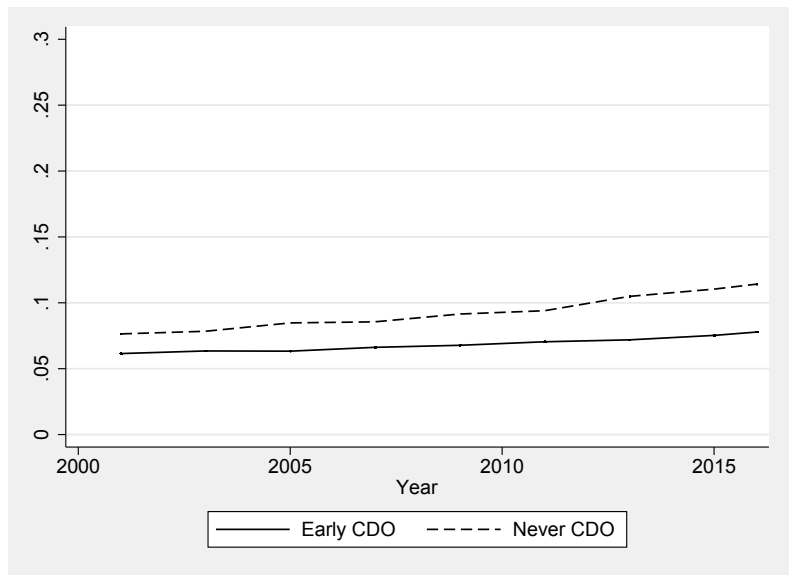

(e) Underrepresented Faculty - Early

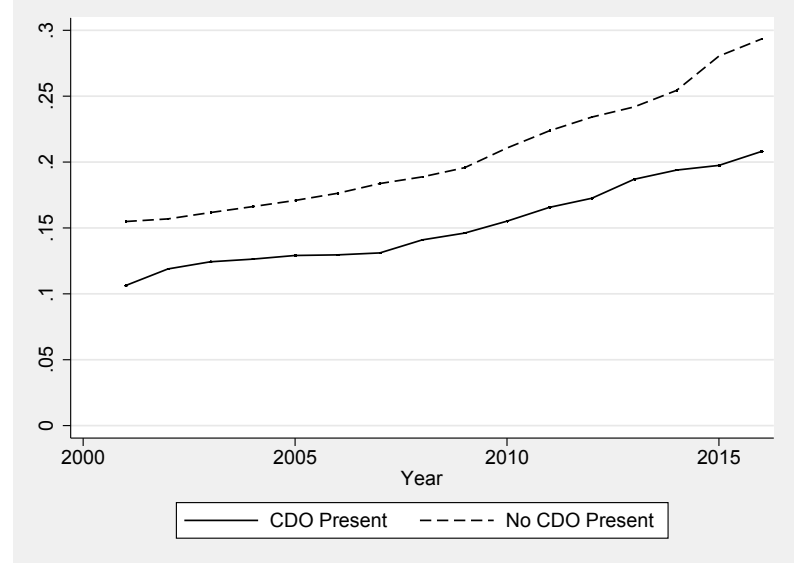

(b) Underrepresented Students

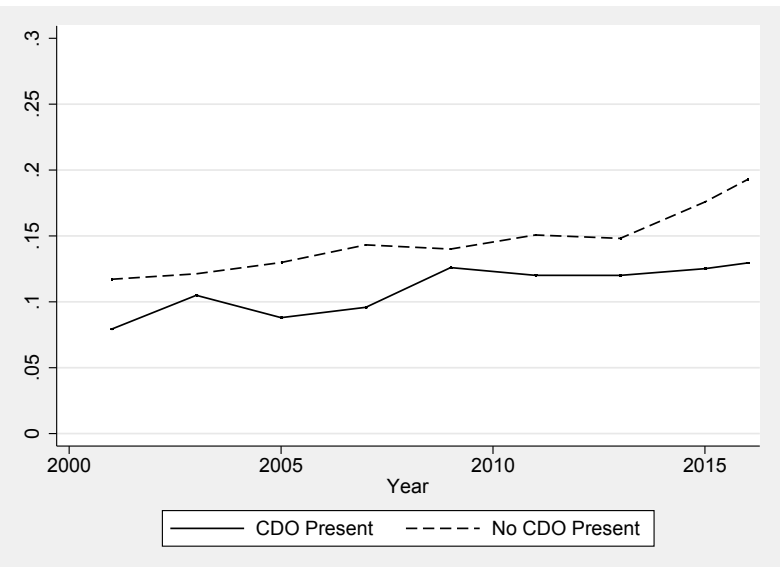

(d) Underrepresented Administrators by CDO

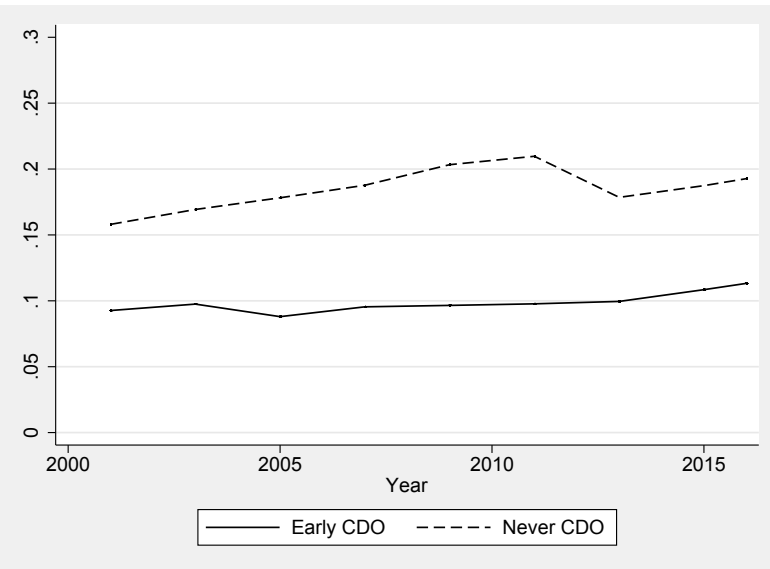

(f) Underrepresented Administrators - Early

Notes: Panels (c) through (f) omit voluntarily reported diversity data and display only academic years in which reporting is mandatory. 


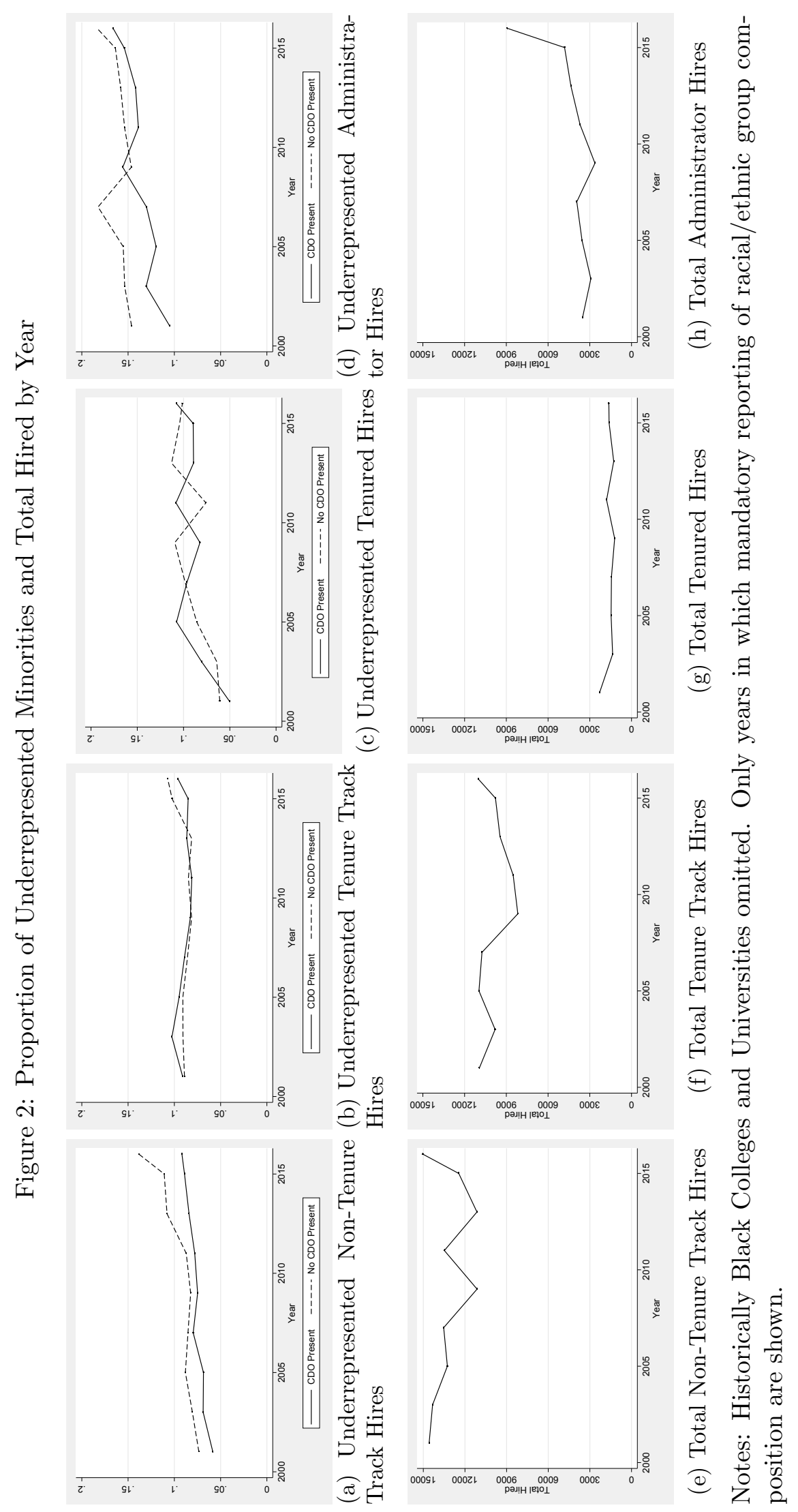


Table 1: Summary Statistics

\begin{tabular}{|c|c|c|c|c|c|c|}
\hline VARIABLES & $\begin{array}{c}(1) \\
\text { Full } \\
\text { Sample } \\
\text { mean } \\
(\mathrm{sd})\end{array}$ & $\begin{array}{c}(2) \\
\text { Mandatory } \\
\text { Reporting } \\
\text { mean } \\
(\mathrm{sd})\end{array}$ & $\begin{array}{c}(3) \\
\text { Carnegie } \\
\text { R1 } \\
\text { mean } \\
(\mathrm{sd})\end{array}$ & $\begin{array}{c}(4) \\
\text { Carnegie } \\
\text { R2 } \\
\text { mean } \\
(\mathrm{sd})\end{array}$ & $\begin{array}{c}(5) \\
\text { Carnegie } \\
\text { M1 } \\
\text { mean } \\
(\mathrm{sd})\end{array}$ & $\begin{array}{c}(6) \\
\text { HBCU } \\
\text { mean } \\
(\mathrm{sd})\end{array}$ \\
\hline Chief Diversity Officer & $\begin{array}{c}0.289 \\
(0.453)\end{array}$ & $\begin{array}{c}0.316 \\
(0.465)\end{array}$ & $\begin{array}{c}0.442 \\
(0.497)\end{array}$ & $\begin{array}{c}0.254 \\
(0.436)\end{array}$ & $\begin{array}{c}0.202 \\
(0.402)\end{array}$ & $\begin{array}{c}0.0257 \\
(0.159)\end{array}$ \\
\hline Peer R1 CDOs & $\begin{array}{c}0.443 \\
(0.250)\end{array}$ & $\begin{array}{c}0.474 \\
(0.268)\end{array}$ & $\begin{array}{c}0.441 \\
(0.250)\end{array}$ & $\begin{array}{l}0.441 \\
(0.250)\end{array}$ & $\begin{array}{c}0.445 \\
(0.250)\end{array}$ & $\begin{array}{c}0.440 \\
(0.250)\end{array}$ \\
\hline \% Under-Rep Non-Tenured Hires & $\begin{array}{c}0.111 \\
(0.161)\end{array}$ & $\begin{array}{l}0.113 \\
(0.158)\end{array}$ & $\begin{array}{c}0.113 \\
(0.158)\end{array}$ & $\begin{array}{l}0.115 \\
(0.167)\end{array}$ & $\begin{array}{c}0.132 \\
(0.197)\end{array}$ & $\begin{array}{c}0.656 \\
(0.228)\end{array}$ \\
\hline \% Under-Rep Tenure-Track Hires & $\begin{array}{c}0.107 \\
(0.133)\end{array}$ & $\begin{array}{l}0.107 \\
(0.131)\end{array}$ & $\begin{array}{c}0.107 \\
(0.131)\end{array}$ & $\begin{array}{c}0.101 \\
(0.131)\end{array}$ & $\begin{array}{c}0.124 \\
(0.165)\end{array}$ & $\begin{array}{c}0.572 \\
(0.247)\end{array}$ \\
\hline \% Under-Rep Tenured Hires & $\begin{array}{c}0.107 \\
(0.221)\end{array}$ & $\begin{array}{c}0.106 \\
(0.222)\end{array}$ & $\begin{array}{c}0.0960 \\
(0.166)\end{array}$ & $\begin{array}{c}0.103 \\
(0.236)\end{array}$ & $\begin{array}{l}0.127 \\
(0.280)\end{array}$ & $\begin{array}{c}0.639 \\
(0.406)\end{array}$ \\
\hline \% Under-Rep Administrator Hires & $\begin{array}{c}0.165 \\
(0.246)\end{array}$ & $\begin{array}{c}0.168 \\
(0.247)\end{array}$ & $\begin{array}{c}0.168 \\
(0.247)\end{array}$ & $\begin{array}{c}0.161 \\
(0.251)\end{array}$ & $\begin{array}{c}0.189 \\
(0.290)\end{array}$ & $\begin{array}{c}0.820 \\
(0.263)\end{array}$ \\
\hline \% Under-Rep Faculty & $\begin{array}{c}0.0996 \\
(0.114)\end{array}$ & $\begin{array}{c}0.1000 \\
(0.113)\end{array}$ & $\begin{array}{c}0.1000 \\
(0.113)\end{array}$ & $\begin{array}{c}0.106 \\
(0.136)\end{array}$ & $\begin{array}{c}0.119 \\
(0.138)\end{array}$ & $\begin{array}{c}0.636 \\
(0.0889)\end{array}$ \\
\hline$\%$ Under-Rep Admin & $\begin{array}{c}0.148 \\
(0.165)\end{array}$ & $\begin{array}{c}0.149 \\
(0.164)\end{array}$ & $\begin{array}{c}0.149 \\
(0.164)\end{array}$ & $\begin{array}{c}0.155 \\
(0.191)\end{array}$ & $\begin{array}{c}0.174 \\
(0.197)\end{array}$ & $\begin{array}{c}0.866 \\
(0.0750)\end{array}$ \\
\hline \% Under-Rep Students & $\begin{array}{c}0.213 \\
(0.195)\end{array}$ & $\begin{array}{l}0.215 \\
(0.196)\end{array}$ & $\begin{array}{c}0.162 \\
(0.114)\end{array}$ & $\begin{array}{l}0.242 \\
(0.220)\end{array}$ & $\begin{array}{c}0.235 \\
(0.220)\end{array}$ & $\begin{array}{c}0.915 \\
(0.0677)\end{array}$ \\
\hline 9 Month Assistant Prof Salary & $\begin{array}{l}72.75 \\
(12.35)\end{array}$ & $\begin{array}{c}72.95 \\
(12.49)\end{array}$ & $\begin{array}{l}82.19 \\
(12.01)\end{array}$ & $\begin{array}{c}72.41 \\
(10.63)\end{array}$ & $\begin{array}{c}66.70 \\
(8.775)\end{array}$ & $\begin{array}{c}64.72 \\
(7.892)\end{array}$ \\
\hline Total In-State Price & $\begin{array}{l}25.38 \\
(14.69)\end{array}$ & $\begin{array}{l}25.85 \\
(14.84)\end{array}$ & $\begin{array}{c}29.97 \\
(16.99)\end{array}$ & $\begin{array}{c}25.66 \\
(14.64)\end{array}$ & $\begin{array}{c}22.28 \\
(12.06)\end{array}$ & $\begin{array}{l}17.41 \\
(6.709)\end{array}$ \\
\hline Total Out-of-State Price & $\begin{array}{l}31.75 \\
(10.99)\end{array}$ & $\begin{array}{c}32.41 \\
(11.10)\end{array}$ & $\begin{array}{c}37.66 \\
(11.82)\end{array}$ & $\begin{array}{c}31.60 \\
(10.38)\end{array}$ & $\begin{array}{c}27.93 \\
(8.678)\end{array}$ & $\begin{array}{l}23.75 \\
(5.130)\end{array}$ \\
\hline Percent of Students In State & $\begin{array}{l}81.83 \\
(18.48)\end{array}$ & $\begin{array}{l}81.78 \\
(18.93)\end{array}$ & $\begin{array}{l}81.78 \\
(18.93)\end{array}$ & $\begin{array}{l}81.59 \\
(18.25)\end{array}$ & $\begin{array}{l}87.37 \\
(16.37)\end{array}$ & $\begin{array}{c}68.62 \\
(19.55)\end{array}$ \\
\hline Percent Receiving Financial Aid & $\begin{array}{l}80.66 \\
(13.57)\end{array}$ & $\begin{array}{l}80.84 \\
(13.66)\end{array}$ & $\begin{array}{c}75.90 \\
(13.22)\end{array}$ & $\begin{array}{l}84.04 \\
(12.37)\end{array}$ & $\begin{array}{l}82.57 \\
(13.37)\end{array}$ & $\begin{array}{l}89.25 \\
(11.42)\end{array}$ \\
\hline Percentage Receiving Student Loan & $\begin{array}{l}50.86 \\
(17.07)\end{array}$ & $\begin{array}{c}50.86 \\
(17.01)\end{array}$ & $\begin{array}{l}43.31 \\
(14.31)\end{array}$ & $\begin{array}{c}53.51 \\
(15.71)\end{array}$ & $\begin{array}{c}54.86 \\
(17.56)\end{array}$ & $\begin{array}{c}70.97 \\
(17.73)\end{array}$ \\
\hline Avg Student Loan Received & $\begin{array}{l}5,416 \\
(2,004)\end{array}$ & $\begin{array}{l}5,505 \\
(2,024)\end{array}$ & $\begin{array}{l}5,548 \\
(1,862)\end{array}$ & $\begin{array}{l}5,703 \\
(2,152)\end{array}$ & $\begin{array}{l}5,227 \\
(2,020)\end{array}$ & $\begin{array}{c}5,683 \\
(2,375)\end{array}$ \\
\hline Growth in Applicants & $\begin{array}{c}0.0596 \\
(0.171)\end{array}$ & $\begin{array}{c}0.0560 \\
(0.172)\end{array}$ & $\begin{array}{c}0.0563 \\
(0.103)\end{array}$ & $\begin{array}{c}0.0715 \\
(0.217)\end{array}$ & $\begin{array}{c}0.0577 \\
(0.189)\end{array}$ & $\begin{array}{c}0.0750 \\
(0.307)\end{array}$ \\
\hline Observations & 7,164 & 4,017 & 2,331 & 1,270 & 3,563 & 272 \\
\hline Number of Universities & 462 & 460 & 147 & 82 & 233 & 17 \\
\hline
\end{tabular}


Table 2: New PhDs Awarded in 2016 to U.S. Citizens and Permanent Residents

\begin{tabular}{|c|c|c|c|c|c|c|c|}
\hline $\begin{array}{l}\text { Field and } \\
\text { Subfield } \\
\text { of Study }\end{array}$ & $\begin{array}{c}\text { U.S. Citizen } \\
\text { and Permanent } \\
\text { Resident } \\
\text { Grand Total } \\
\text { num }\end{array}$ & $\begin{array}{l}\text { American } \\
\text { Indian } \\
\text { or Alaskan } \\
\text { Native } \\
\text { num } \\
\text { (pct) }\end{array}$ & $\begin{array}{c}\text { Black } \\
\text { num } \\
\text { (pct) }\end{array}$ & $\begin{array}{l}\text { Hispanic } \\
\text { num } \\
\text { (pct) }\end{array}$ & $\begin{array}{c}\text { Asian } \\
\text { num } \\
\text { (pct) }\end{array}$ & $\begin{array}{l}\text { White } \\
\text { num } \\
\text { (pct) }\end{array}$ & $\begin{array}{c}\text { Under- } \\
\text { Represented } \\
\text { Total } \\
\text { num } \\
\text { (pct) }\end{array}$ \\
\hline Life Sciences & 8,697 & $\begin{array}{c}27 \\
(0.3 \%)\end{array}$ & $\begin{array}{c}510 \\
(5.9 \%)\end{array}$ & $\begin{array}{c}655 \\
(7.5 \%)\end{array}$ & $\begin{array}{c}915 \\
(10.5 \%)\end{array}$ & $\begin{array}{l}6,118 \\
(70.3 \%)\end{array}$ & $\begin{array}{l}1,192 \\
(13.7 \%)\end{array}$ \\
\hline Biological and Biomedical Sciences & 6,225 & $\begin{array}{c}11 \\
(0.2 \%)\end{array}$ & $\begin{array}{c}280 \\
(4.5 \%)\end{array}$ & $\begin{array}{c}494 \\
(7.9 \%)\end{array}$ & $\begin{array}{c}708 \\
(11.4 \%)\end{array}$ & $\begin{array}{l}4,376 \\
(70.3 \%)\end{array}$ & $\begin{array}{c}785 \\
(12.6 \%)\end{array}$ \\
\hline Health Sciences & 1,699 & $\begin{array}{c}11 \\
(0.6 \%)\end{array}$ & $\begin{array}{c}200 \\
(11.8 \%)\end{array}$ & $\begin{array}{c}115 \\
(6.8 \%)\end{array}$ & $\begin{array}{l}155 \\
(9.1 \%)\end{array}$ & $\begin{array}{l}1,141 \\
(67.2 \%)\end{array}$ & $\begin{array}{c}326 \\
(19.2 \%)\end{array}$ \\
\hline Physical Sciences and Earth Sciences & 3,666 & $\begin{array}{c}8 \\
(0.2 \%)\end{array}$ & $\begin{array}{c}97 \\
(2.6 \%)\end{array}$ & $\begin{array}{c}186 \\
(5.1 \%)\end{array}$ & $\begin{array}{c}302 \\
(8.2 \%)\end{array}$ & $\begin{array}{l}2,876 \\
(78.5 \%)\end{array}$ & $\begin{array}{c}291 \\
(7.9 \%)\end{array}$ \\
\hline Chemistry & 1,579 & $\begin{array}{c}2 \\
(0.1 \%)\end{array}$ & $\begin{array}{c}64 \\
(4.1 \%)\end{array}$ & $\begin{array}{c}87 \\
(5.5 \%)\end{array}$ & $\begin{array}{l}150 \\
(9.5 \%)\end{array}$ & $\begin{array}{l}1,190 \\
(75.4 \%)\end{array}$ & $\begin{array}{c}153 \\
(9.7 \%)\end{array}$ \\
\hline Geosciences \& Atmospheric \& Ocean Sciences & 802 & $\begin{array}{c}4 \\
(0.5 \%)\end{array}$ & $\begin{array}{c}10 \\
(1.2 \%)\end{array}$ & $\begin{array}{c}42 \\
(5.2 \%)\end{array}$ & $\begin{array}{c}49 \\
(6.1 \%)\end{array}$ & $\begin{array}{c}661 \\
(82.4 \%)\end{array}$ & $\begin{array}{c}56 \\
(7.0 \%)\end{array}$ \\
\hline Physics and Astronomy & 1,285 & $\begin{array}{c}2 \\
(0.2 \%)\end{array}$ & $\begin{array}{c}23 \\
(1.8 \%)\end{array}$ & $\begin{array}{c}57 \\
(4.4 \%)\end{array}$ & $\begin{array}{c}103 \\
(8.0 \%)\end{array}$ & $\begin{array}{l}1,025 \\
(79.8 \%)\end{array}$ & $\begin{array}{c}82 \\
(6.4 \%)\end{array}$ \\
\hline Mathematics and Computer Sciences & 1,730 & $\begin{array}{c}3 \\
(0.2 \%)\end{array}$ & $\begin{array}{c}78 \\
(4.5 \%)\end{array}$ & $\begin{array}{c}96 \\
(5.5 \%)\end{array}$ & $\begin{array}{c}216 \\
(12.5 \%)\end{array}$ & $\begin{array}{l}1,208 \\
(69.8 \%)\end{array}$ & $\begin{array}{c}177 \\
(10.2 \%)\end{array}$ \\
\hline Psychology and Social Sciences & 6,830 & $\begin{array}{c}30 \\
(0.4 \%)\end{array}$ & $\begin{array}{c}495 \\
(7.2 \%)\end{array}$ & $\begin{array}{c}583 \\
(8.5 \%)\end{array}$ & $\begin{array}{c}428 \\
(6.3 \%)\end{array}$ & $\begin{array}{l}4,846 \\
(71.0 \%)\end{array}$ & $\begin{array}{l}1,108 \\
(16.2 \%)\end{array}$ \\
\hline Psychology & 3,371 & $\begin{array}{c}11 \\
(0.3 \%)\end{array}$ & $\begin{array}{c}232 \\
(6.9 \%)\end{array}$ & $\begin{array}{c}306 \\
(9.1 \%)\end{array}$ & $\begin{array}{l}188 \\
(5.6 \%)\end{array}$ & $\begin{array}{l}2,406 \\
(71.4 \%)\end{array}$ & $\begin{array}{c}549 \\
(16.3 \%)\end{array}$ \\
\hline Social Sciences & 3,459 & $\begin{array}{c}19 \\
(0.5 \%)\end{array}$ & $\begin{array}{c}263 \\
(7.6 \%)\end{array}$ & $\begin{array}{c}277 \\
(8.0 \%)\end{array}$ & $\begin{array}{l}240 \\
(6.9 \%)\end{array}$ & $\begin{array}{l}2,440 \\
(70.5 \%)\end{array}$ & $\begin{array}{c}559 \\
(16.2 \%)\end{array}$ \\
\hline Economics & 521 & $\begin{array}{c}1 \\
(0.2 \%)\end{array}$ & $\begin{array}{c}18 \\
(3.5 \%)\end{array}$ & $\begin{array}{c}31 \\
(6.0 \%)\end{array}$ & $\begin{array}{c}61 \\
(11.7 \%)\end{array}$ & $\begin{array}{c}378 \\
(72.6 \%)\end{array}$ & $\begin{array}{c}50 \\
(9.6 \%)\end{array}$ \\
\hline Political Science and Government & 579 & $\begin{array}{c}3 \\
(0.5 \%)\end{array}$ & $\begin{array}{c}27 \\
(4.7 \%)\end{array}$ & $\begin{array}{c}43 \\
(7.4 \%)\end{array}$ & $\begin{array}{c}29 \\
(5.0 \%)\end{array}$ & $\begin{array}{c}441 \\
(76.2 \%)\end{array}$ & $\begin{array}{c}73 \\
(12.6 \%)\end{array}$ \\
\hline Sociology & 508 & $\begin{array}{c}1 \\
(0.2 \%)\end{array}$ & $\begin{array}{c}43 \\
(8.5 \%)\end{array}$ & $\begin{array}{c}33 \\
(6.5 \%)\end{array}$ & $\begin{array}{c}32 \\
(6.3 \%)\end{array}$ & $\begin{array}{c}365 \\
(71.9 \%)\end{array}$ & $\begin{array}{c}77 \\
(15.2 \%)\end{array}$ \\
\hline Other social sciences & 1,491 & $\begin{array}{c}9 \\
(0.6 \%)\end{array}$ & $\begin{array}{c}158 \\
(10.6 \%)\end{array}$ & $\begin{array}{c}132 \\
(8.9 \%)\end{array}$ & $\begin{array}{c}103 \\
(6.9 \%)\end{array}$ & $\begin{array}{c}991 \\
(66.5 \%)\end{array}$ & $\begin{array}{c}299 \\
(20.1 \%)\end{array}$ \\
\hline Area \& Ethnic \& Cultural \& Gender Studies & 220 & $\begin{array}{c}44 \\
(0.9 \%)\end{array}$ & $\begin{array}{c}38 \\
(20.0 \%)\end{array}$ & $\begin{array}{c}2 \\
(17.3 \%)\end{array}$ & $\begin{array}{c}21 \\
(9.5 \%)\end{array}$ & $\begin{array}{c}98 \\
(44.5 \%)\end{array}$ & $\begin{array}{c}84 \\
(38.2 \%)\end{array}$ \\
\hline Engineering & 4,181 & $\begin{array}{c}8 \\
(0.2 \%)\end{array}$ & $\begin{array}{c}173 \\
(4.1 \%)\end{array}$ & $\begin{array}{c}271 \\
(6.5 \%)\end{array}$ & $\begin{array}{c}642 \\
(15.4 \%)\end{array}$ & $\begin{array}{l}2,810 \\
(67.2 \%)\end{array}$ & $\begin{array}{c}452 \\
(10.8 \%)\end{array}$ \\
\hline Education & 4,303 & $\begin{array}{c}30 \\
(0.7 \%)\end{array}$ & $\begin{array}{c}640 \\
(14.9 \%)\end{array}$ & $\begin{array}{c}322 \\
(7.5 \%)\end{array}$ & $\begin{array}{c}210 \\
(4.9 \%)\end{array}$ & $\begin{array}{l}2,889 \\
(67.1 \%)\end{array}$ & $\begin{array}{c}992 \\
(23.1 \%)\end{array}$ \\
\hline Education Administration & 730 & $\begin{array}{c}6 \\
(0.8 \%)\end{array}$ & $\begin{array}{c}171 \\
(23.4 \%)\end{array}$ & $\begin{array}{c}44 \\
(6.0 \%)\end{array}$ & $\begin{array}{c}17 \\
(2.3 \%)\end{array}$ & $\begin{array}{c}456 \\
(62.5 \%)\end{array}$ & $\begin{array}{c}221 \\
(30.3 \%)\end{array}$ \\
\hline Teacher Education & 159 & $\begin{array}{c}2 \\
(1.3 \%)\end{array}$ & $\begin{array}{c}26 \\
(16.4 \%)\end{array}$ & $\begin{array}{c}5 \\
(3.1 \%)\end{array}$ & $\begin{array}{c}5 \\
(3.1 \%)\end{array}$ & $\begin{array}{c}111 \\
(69.8 \%)\end{array}$ & $\begin{array}{c}33 \\
(20.8 \%)\end{array}$ \\
\hline Humanities and Arts & 4,447 & $\begin{array}{c}19 \\
(0.4 \%)\end{array}$ & $\begin{array}{c}170 \\
(3.8 \%)\end{array}$ & $\begin{array}{c}318 \\
(7.2 \%)\end{array}$ & $\begin{array}{c}180 \\
(4.0 \%)\end{array}$ & $\begin{array}{l}3,527 \\
(79.3 \%)\end{array}$ & $\begin{array}{c}507 \\
(11.4 \%)\end{array}$ \\
\hline Foreign Languages and Literature & 399 & $\begin{array}{c}2 \\
(0.5 \%)\end{array}$ & $\begin{array}{c}3 \\
(0.8 \%)\end{array}$ & $\begin{array}{c}92 \\
(23.1 \%)\end{array}$ & $\begin{array}{c}13 \\
(3.3 \%)\end{array}$ & $\begin{array}{c}273 \\
(68.4 \%)\end{array}$ & $\begin{array}{c}97 \\
(24.3 \%)\end{array}$ \\
\hline History & 949 & $\begin{array}{c}3 \\
(0.3 \%)\end{array}$ & $\begin{array}{c}51 \\
(5.4 \%)\end{array}$ & $\begin{array}{c}76 \\
(8.0 \%)\end{array}$ & $\begin{array}{c}34 \\
(3.6 \%)\end{array}$ & $\begin{array}{c}735 \\
(77.4 \%)\end{array}$ & $\begin{array}{c}130 \\
(13.7 \%)\end{array}$ \\
\hline Latin American History & 60 & $\begin{array}{c}0 \\
(0.0 \%)\end{array}$ & $\begin{array}{c}3 \\
(5.0 \%)\end{array}$ & $\begin{array}{c}21 \\
(35.0 \%)\end{array}$ & $\begin{array}{c}0 \\
(0.0 \%)\end{array}$ & $\begin{array}{c}36 \\
(60.0 \%)\end{array}$ & $\begin{array}{c}24 \\
(40.0 \%)\end{array}$ \\
\hline Non-Science and Engineering -Other Fields & 1,865 & $\begin{array}{c}3 \\
(0.2 \%)\end{array}$ & $\begin{array}{c}197 \\
(10.6 \%)\end{array}$ & $\begin{array}{c}124 \\
(6.6 \%)\end{array}$ & $\begin{array}{c}189 \\
(10.1 \%)\end{array}$ & $\begin{array}{l}1,250 \\
(67.0 \%)\end{array}$ & $\begin{array}{c}324 \\
(17.4 \%)\end{array}$ \\
\hline Business Management and Administration & 845 & $\begin{array}{c}3 \\
(0.4 \%)\end{array}$ & $\begin{array}{c}81 \\
(9.6 \%)\end{array}$ & $\begin{array}{c}56 \\
(6.6 \%)\end{array}$ & $\begin{array}{c}122 \\
(14.4 \%)\end{array}$ & $\begin{array}{c}538 \\
(63.7 \%)\end{array}$ & $\begin{array}{c}140 \\
(16.6 \%)\end{array}$ \\
\hline Public Administration & 103 & $\begin{array}{c}0 \\
(0.0 \%) \\
\end{array}$ & $\begin{array}{c}26 \\
(25.2 \%) \\
\end{array}$ & $\begin{array}{c}5 \\
(4.9 \%) \\
\end{array}$ & $\begin{array}{c}5 \\
(4.9 \%) \\
\end{array}$ & $\begin{array}{c}62 \\
(60.2 \%) \\
\end{array}$ & $\begin{array}{c}31 \\
(30.1 \%) \\
\end{array}$ \\
\hline Grand Total - All Fields & 35,719 & $\begin{array}{c}128 \\
(0.4 \%)\end{array}$ & $\begin{array}{l}2,360 \\
(6.6 \%)\end{array}$ & $\begin{array}{l}2,555 \\
(7.2 \%)\end{array}$ & $\begin{array}{l}3,082 \\
(8.6 \%)\end{array}$ & $\begin{array}{c}25,524 \\
(71.5 \%)\end{array}$ & $\begin{array}{l}5,043 \\
(14.1 \%)\end{array}$ \\
\hline
\end{tabular}

Notes: Data tabulated from National Science Foundation (2018, Table 22). 
Table 3: Granger Causality Test

\begin{tabular}{|c|c|c|c|c|c|}
\hline VARIABLES & $\begin{array}{c}(2) \\
\text { New CDO }\end{array}$ & $\begin{array}{c}(3) \\
\Delta \% \text { Under-Rep } \\
\text { Students }\end{array}$ & $\begin{array}{c}(4) \\
\Delta \% \text { Under-Rep } \\
\text { Faculty }\end{array}$ & $\begin{array}{c}(5) \\
\Delta \% \text { Under-Rep } \\
\text { Admin }\end{array}$ & $\begin{array}{c}\text { (6) } \\
\text { Applications } \\
\text { Growth }\end{array}$ \\
\hline \multicolumn{6}{|l|}{ Panel A: Full Sample } \\
\hline New CDO & - & $\begin{array}{c}1.81 \\
{[0.107]}\end{array}$ & $\begin{array}{c}0.23 \\
{[0.866]}\end{array}$ & $\begin{array}{c}1.6 \\
{[0.949]}\end{array}$ & $\begin{array}{c}1.04 \\
{[0.391]}\end{array}$ \\
\hline$\Delta \%$ Under-Rep Students & $\begin{array}{c}1.35 \\
{[0.242]}\end{array}$ & - & $\begin{array}{l}2.80^{* *} \\
{[0.016]}\end{array}$ & $\begin{array}{l}1.86^{*} \\
{[0.099]}\end{array}$ & $\begin{array}{c}5.59^{* * *} \\
{[0.000]}\end{array}$ \\
\hline$\Delta \%$ Under-Rep Faculty & $\begin{array}{c}1.34 \\
{[0.243]}\end{array}$ & $\begin{array}{l}1.86^{* *} \\
{[0.098]}\end{array}$ & - & $\begin{array}{c}1.61 \\
{[0.154]}\end{array}$ & $\begin{array}{c}3.17^{* * *} \\
{[0.007]}\end{array}$ \\
\hline$\Delta \%$ Under-Rep Admin & $\begin{array}{l}2.59^{* *} \\
{[0.024]}\end{array}$ & $\begin{array}{l}2.64^{* *} \\
{[0.022]}\end{array}$ & $\begin{array}{l}2.80^{* *} \\
{[0.016]}\end{array}$ & - & $\begin{array}{c}1.77 \\
{[0.115]}\end{array}$ \\
\hline Applicant Growth & $\begin{array}{c}2.59^{* *} \\
{[0.024]}\end{array}$ & $\begin{array}{c}0.58 \\
{[0.713]}\end{array}$ & $\begin{array}{c}6.79^{* * *} \\
{[0.000]}\end{array}$ & $\begin{array}{c}1.29 \\
{[0.264]}\end{array}$ & - \\
\hline $\begin{array}{l}\text { Observations } \\
\text { Number of Universities }\end{array}$ & $\begin{array}{c}4,375 \\
455\end{array}$ & $\begin{array}{c}4,374 \\
455\end{array}$ & $\begin{array}{c}4,374 \\
455\end{array}$ & $\begin{array}{c}4,374 \\
455\end{array}$ & $\begin{array}{c}4,363 \\
455\end{array}$ \\
\hline \multicolumn{6}{|l|}{ Panel B: HBCU Omitted } \\
\hline New CDO & - & $\begin{array}{l}1.94^{*} \\
{[0.084]}\end{array}$ & $\begin{array}{c}0.23 \\
{[0.949]}\end{array}$ & $\begin{array}{c}1.68 \\
{[0.135]}\end{array}$ & $\begin{array}{c}1.09 \\
{[0.362]}\end{array}$ \\
\hline$\Delta \%$ Under-Rep Students & $\begin{array}{l}2.00^{*} \\
{[0.076]}\end{array}$ & - & $\begin{array}{c}4.16^{* * *} \\
{[0.001]}\end{array}$ & $\begin{array}{c}4.01^{* * *} \\
{[0.001]}\end{array}$ & $\begin{array}{c}6.98^{* * *} \\
{[0.000]}\end{array}$ \\
\hline$\Delta \%$ Under-Rep Faculty & $\begin{array}{c}1.65 \\
{[0.144]}\end{array}$ & $\begin{array}{c}1.82 \\
{[0.106]}\end{array}$ & - & $\begin{array}{c}1.36 \\
{[0.237]}\end{array}$ & $\begin{array}{l}4.46^{* * *} \\
{[0.001]}\end{array}$ \\
\hline$\Delta \%$ Under-Rep Admin & $\begin{array}{l}2.12^{*} \\
{[0.060]}\end{array}$ & $\begin{array}{c}3.25^{* * *} \\
{[0.006]}\end{array}$ & $\begin{array}{c}4.03^{* * *} \\
{[0.001]}\end{array}$ & - & $\begin{array}{c}0.66 \\
{[0.651]}\end{array}$ \\
\hline Applications Growth & $\begin{array}{l}2.92^{* *} \\
{[0.012]}\end{array}$ & $\begin{array}{c}1.61 \\
{[0.155]}\end{array}$ & $\begin{array}{c}4.76^{* * *} \\
{[0.000]}\end{array}$ & $\begin{array}{l}2.00^{*} \\
{[0.075]}\end{array}$ & - \\
\hline $\begin{array}{l}\text { Observations } \\
\text { Number of Universities }\end{array}$ & $\begin{array}{c}4,238 \\
438\end{array}$ & $\begin{array}{c}4,237 \\
438\end{array}$ & $\begin{array}{c}4,237 \\
438\end{array}$ & $\begin{array}{c}4,237 \\
438\end{array}$ & $\begin{array}{c}4,229 \\
438\end{array}$ \\
\hline
\end{tabular}

Each cell is an $F$-statistic excluding lags 1-5 of the indicated variable. $p$-values are beneath each $F$-statistic in brackets. Underrepresented minorities defined as Black, Hispanic, and Native American/Pacific Islander. Missing explanatory variables imputed linearly. ${ }^{* * *} p<0.01,{ }^{* *} p<0.05,{ }^{*}$ $p<0.1$. 
Table 4: FE Regressions of CDO on Percentage of Diversity Hires by Hiring Category

\begin{tabular}{|c|c|c|c|c|c|}
\hline VARIABLES & $\begin{array}{c}(1) \\
\text { Non Tenured }\end{array}$ & $\begin{array}{c}(2) \\
\text { Tenure Track }\end{array}$ & $\begin{array}{c}(3) \\
\text { Tenured }\end{array}$ & $\begin{array}{c}(4) \\
\text { Admin }\end{array}$ & $\begin{array}{c}(5) \\
\Delta \text { Grad Students }\end{array}$ \\
\hline \multicolumn{6}{|l|}{ Panel A: Full Sample } \\
\hline Chief Diversity Officer & $\begin{array}{r}0.0080 \\
(0.007)\end{array}$ & $\begin{array}{c}-0.0058 \\
(0.006)\end{array}$ & $\begin{array}{c}-0.0238 \\
(0.015)\end{array}$ & $\begin{array}{c}0.0124 \\
(0.013)\end{array}$ & $\begin{array}{r}0.0010 \\
(0.001)\end{array}$ \\
\hline$\Delta \%$ Under-Rep Students & $\begin{array}{c}-0.1501 \\
(0.146)\end{array}$ & $\begin{array}{l}0.0233 \\
(0.185)\end{array}$ & $\begin{array}{c}-0.3435 \\
(0.438)\end{array}$ & $\begin{array}{c}-0.0468 \\
(0.178)\end{array}$ & $\begin{array}{r}0.0400 \\
(0.056)\end{array}$ \\
\hline$\Delta \%$ Under-Rep Faculty & $\begin{array}{c}0.6229^{*} \\
(0.329)\end{array}$ & $\begin{array}{c}0.9429^{* * *} \\
\quad(0.258)\end{array}$ & $\begin{array}{c}-0.4393 \\
(0.640)\end{array}$ & $\begin{array}{c}0.0074 \\
(0.347)\end{array}$ & $\begin{array}{r}0.0308 \\
(0.100)\end{array}$ \\
\hline$\Delta \%$ Under-Rep Administrators & $\begin{array}{l}0.0955 \\
(0.128)\end{array}$ & $\begin{array}{c}-0.0927 \\
(0.080)\end{array}$ & $\begin{array}{c}-0.0302 \\
(0.289)\end{array}$ & $\begin{array}{c}0.6280^{* * *} \\
(0.172)\end{array}$ & $\begin{array}{c}-0.0045 \\
(0.025)\end{array}$ \\
\hline Growth in Applicants & $\begin{array}{r}0.0040 \\
(0.014)\end{array}$ & $\begin{array}{c}-0.0195^{*} \\
(0.011)\end{array}$ & $\begin{array}{c}-0.0293 \\
(0.039)\end{array}$ & $\begin{array}{c}-0.0284 \\
(0.025)\end{array}$ & $\begin{array}{c}-0.0028 \\
(0.003)\end{array}$ \\
\hline $\begin{array}{l}\text { Observations } \\
\text { Number of Universities } \\
R^{2}\end{array}$ & $\begin{array}{c}3,262 \\
456 \\
0.015\end{array}$ & $\begin{array}{c}3,392 \\
454 \\
0.017\end{array}$ & $\begin{array}{c}2,005 \\
397 \\
0.009\end{array}$ & $\begin{array}{c}3,181 \\
461 \\
0.015\end{array}$ & $\begin{array}{c}6,256 \\
461 \\
0.066\end{array}$ \\
\hline \multicolumn{6}{|l|}{ Panel B: HBCU Omitted } \\
\hline Chief Diversity Officer & $\begin{array}{c}0.0094 \\
(0.007)\end{array}$ & $\begin{array}{c}-0.0083 \\
(0.006)\end{array}$ & $\begin{array}{c}-0.0284^{*} \\
(0.015)\end{array}$ & $\begin{array}{l}0.0106 \\
(0.013)\end{array}$ & $\begin{array}{c}0.0003 \\
(0.001)\end{array}$ \\
\hline$\Delta \%$ Under-Rep Students & $\begin{array}{l}0.0188 \\
(0.232)\end{array}$ & $\begin{array}{c}-0.0044 \\
(0.193)\end{array}$ & $\begin{array}{c}-0.4641 \\
(0.502)\end{array}$ & $\begin{array}{c}-0.0651 \\
(0.334)\end{array}$ & $\begin{array}{l}0.0456 \\
(0.074)\end{array}$ \\
\hline$\Delta \%$ Under-Rep Faculty & $\begin{array}{l}0.3532 \\
(0.287)\end{array}$ & $\begin{array}{c}1.0962^{* * *} \\
(0.215)\end{array}$ & $\begin{array}{l}0.3191 \\
(0.492)\end{array}$ & $\begin{array}{c}-0.1268 \\
(0.390)\end{array}$ & $\begin{array}{c}-0.0592 \\
(0.100)\end{array}$ \\
\hline$\Delta \%$ Under-Rep Administrators & $\begin{array}{c}0.0573 \\
(0.123)\end{array}$ & $\begin{array}{c}-0.1168 \\
(0.071)\end{array}$ & $\begin{array}{c}-0.0113 \\
(0.242)\end{array}$ & $\begin{array}{c}0.6516^{* * *} \\
(0.174)\end{array}$ & $\begin{array}{c}-0.0074 \\
(0.025)\end{array}$ \\
\hline Growth in Applicants & $\begin{array}{c}0.0094 \\
(0.013)\end{array}$ & $\begin{array}{c}-0.0182^{*} \\
(0.010)\end{array}$ & $\begin{array}{c}-0.0187 \\
(0.035)\end{array}$ & $\begin{array}{c}-0.0205 \\
(0.025)\end{array}$ & $\begin{array}{c}-0.0015 \\
(0.003)\end{array}$ \\
\hline Observations & 3,154 & 3,298 & 1,960 & 3,089 & 6,043 \\
\hline Number of Universities & 439 & 437 & 381 & 444 & 444 \\
\hline$R^{2}$ & 0.011 & 0.021 & 0.009 & 0.016 & 0.091 \\
\hline
\end{tabular}

All specifications include university and annual fixed effects. Underrepresented minorities defined as Black, Hispanic, and Native American/Pacific Islander. Columns 1 through 4 estimated in years where hiring demographic reporting is mandatory. ${ }^{* * *} p<0.01,{ }^{* *} p<0.05,{ }^{*} p<0.1$. 
Table 5: IV Regressions of CDO on Percentage of Diversity Hires by Hiring Category

\begin{tabular}{|c|c|c|c|c|c|c|}
\hline VARIABLES & $\begin{array}{c}(1) \\
\text { First Stage }\end{array}$ & $\begin{array}{c}(2) \\
\text { Non Tenured }\end{array}$ & $\begin{array}{c}(3) \\
\text { Tenure Track }\end{array}$ & $\begin{array}{c}(4) \\
\text { Tenured }\end{array}$ & $\begin{array}{c}(5) \\
\text { Admin }\end{array}$ & $\begin{array}{c}(6) \\
\Delta \text { Grad Students }\end{array}$ \\
\hline \multicolumn{7}{|l|}{ Panel A: Full Sample } \\
\hline Chief Diversity Officer & & $\begin{array}{c}0.0089 \\
(0.011)\end{array}$ & $\begin{array}{r}0.0026 \\
(0.009)\end{array}$ & $\begin{array}{c}-0.0527^{* *} \\
(0.023)\end{array}$ & $\begin{array}{c}-0.0045 \\
(0.020)\end{array}$ & $\begin{array}{c}-0.0015 \\
(0.001)\end{array}$ \\
\hline$\Delta \%$ Under-Rep Students & $\begin{array}{c}0.0853 \\
(0.208)\end{array}$ & $\begin{array}{c}-0.1502 \\
(0.146)\end{array}$ & $\begin{array}{l}0.0222 \\
(0.185)\end{array}$ & $\begin{array}{c}-0.3292 \\
(0.435)\end{array}$ & $\begin{array}{c}-0.0485 \\
(0.178)\end{array}$ & $\begin{array}{c}0.0403 \\
(0.056)\end{array}$ \\
\hline$\Delta \%$ Under-Rep Faculty & $\begin{array}{c}-0.9198^{* *} \\
(0.368)\end{array}$ & $\begin{array}{c}0.6237^{*} \\
(0.330)\end{array}$ & $\begin{array}{c}0.9467^{* * *} \\
(0.259)\end{array}$ & $\begin{array}{c}-0.4577 \\
(0.641)\end{array}$ & $\begin{array}{c}-0.0059 \\
(0.347)\end{array}$ & $\begin{array}{c}0.0289 \\
(0.100)\end{array}$ \\
\hline$\Delta \%$ Under-Rep Administrators & $\begin{array}{c}0.2401 \\
(0.164)\end{array}$ & $\begin{array}{c}0.0954 \\
(0.128)\end{array}$ & $\begin{array}{c}-0.0942 \\
(0.080)\end{array}$ & $\begin{array}{c}-0.0295 \\
(0.290)\end{array}$ & $\begin{array}{c}0.6325^{\text {*** }} \\
(0.172)\end{array}$ & $\begin{array}{c}-0.0037 \\
(0.025)\end{array}$ \\
\hline Growth in Applicants & $\begin{array}{c}-0.0157 \\
(0.027)\end{array}$ & $\begin{array}{l}0.0040 \\
(0.014)\end{array}$ & $\begin{array}{c}-0.0195^{*} \\
(0.011)\end{array}$ & $\begin{array}{c}-0.0290 \\
(0.039)\end{array}$ & $\begin{array}{c}-0.0284 \\
(0.025)\end{array}$ & $\begin{array}{c}-0.0028 \\
(0.003)\end{array}$ \\
\hline Lagged Peer R1 CDOs & $\begin{array}{c}-112.2275^{* * *} \\
(4.081)\end{array}$ & & & & & \\
\hline $\begin{array}{l}\text { Observations } \\
\text { Number of Universities } \\
R^{2}\end{array}$ & $\begin{array}{c}3,262 \\
456 \\
0.492\end{array}$ & $\begin{array}{c}3,262 \\
456\end{array}$ & $\begin{array}{c}3,392 \\
454\end{array}$ & $\begin{array}{c}2,005 \\
397\end{array}$ & $\begin{array}{c}3,181 \\
461\end{array}$ & $\begin{array}{c}6,256 \\
461\end{array}$ \\
\hline First Stage F & & 756.3 & 290.5 & 244.3 & 282.4 & 4030 \\
\hline \multicolumn{7}{|l|}{ Panel B: HBCU Omitted } \\
\hline Chief Diversity Officer & & $\begin{array}{r}0.0070 \\
(0.011)\end{array}$ & $\begin{array}{c}0.0019 \\
(0.009)\end{array}$ & $\begin{array}{c}-0.0561^{* *} \\
(0.023)\end{array}$ & $\begin{array}{c}-0.0029 \\
(0.020)\end{array}$ & $\begin{array}{c}-0.0012 \\
(0.001)\end{array}$ \\
\hline$\Delta \%$ Under-Rep Students & $\begin{array}{c}-0.0244 \\
(0.374)\end{array}$ & $\begin{array}{c}0.0188 \\
(0.232)\end{array}$ & $\begin{array}{c}-0.0057 \\
(0.194)\end{array}$ & $\begin{array}{c}-0.4476 \\
(0.502)\end{array}$ & $\begin{array}{c}-0.0693 \\
(0.333)\end{array}$ & $\begin{array}{l}0.0457 \\
(0.074)\end{array}$ \\
\hline$\Delta \%$ Under-Rep Faculty & $\begin{array}{c}-1.1064^{* *} \\
(0.434)\end{array}$ & $\begin{array}{l}0.3507 \\
(0.287)\end{array}$ & $\begin{array}{l}1.1051^{* * *} \\
\quad(0.216)\end{array}$ & $\begin{array}{c}0.2905 \\
(0.490)\end{array}$ & $\begin{array}{c}-0.1400 \\
(0.389)\end{array}$ & $\begin{array}{c}-0.0607 \\
(0.100)\end{array}$ \\
\hline$\Delta \%$ Under-Rep Administrators & $\begin{array}{l}0.2631 \\
(0.177)\end{array}$ & $\begin{array}{c}0.0578 \\
(0.123)\end{array}$ & $\begin{array}{c}-0.1185^{*} \\
(0.072)\end{array}$ & $\begin{array}{c}-0.0077 \\
(0.243)\end{array}$ & $\begin{array}{c}0.6550^{* * *} \\
(0.174)\end{array}$ & $\begin{array}{c}-0.0069 \\
(0.025)\end{array}$ \\
\hline Growth in Applicants & $\begin{array}{c}-0.0179 \\
(0.028)\end{array}$ & $\begin{array}{c}0.0094 \\
(0.012)\end{array}$ & $\begin{array}{c}-0.0181^{*} \\
(0.010)\end{array}$ & $\begin{array}{c}-0.0181 \\
(0.035)\end{array}$ & $\begin{array}{c}-0.0206 \\
(0.025)\end{array}$ & $\begin{array}{c}-0.0015 \\
(0.003)\end{array}$ \\
\hline Lagged Peer R1 CDOs & $\begin{array}{c}-112.1544^{* * *} \\
(4.073)\end{array}$ & & & & & \\
\hline Observations & 3,154 & 3,154 & 3,298 & 1,960 & 3,089 & 6,043 \\
\hline $\begin{array}{l}\text { Number of Universities } \\
R^{2}\end{array}$ & $\begin{array}{c}439 \\
0.503\end{array}$ & 439 & 437 & 381 & 444 & 444 \\
\hline First Stage F & & 758.3 & 290.9 & 244.3 & 281 & 4259 \\
\hline
\end{tabular}

All specifications include university and annual fixed effects. Underrepresented minorities defined as Black, Hispanic, and Native American/Pacific Islander. Columns 2 through 5 estimated in years where hiring demographic reporting is mandatory. ${ }^{* * *} p<0.01,{ }^{* *} p<0.05,{ }^{*} p<0.1$. 
Table 6: FE Regressions of CDO on Probability of Diversity Hires Relative to Peer Institutions by Hiring Category

\begin{tabular}{|c|c|c|c|c|}
\hline VARIABLES & $\begin{array}{c}(1) \\
\text { Non Tenured }\end{array}$ & $\begin{array}{c}(2) \\
\text { Tenure Track }\end{array}$ & $\begin{array}{c}(3) \\
\text { Tenured }\end{array}$ & $\begin{array}{c}(4) \\
\text { Admin }\end{array}$ \\
\hline \multicolumn{5}{|l|}{ Panel A: Full Sample } \\
\hline Chief Diversity Officer & $\begin{array}{c}-0.0034 \\
(0.017)\end{array}$ & $\begin{array}{c}-0.0162 \\
(0.017)\end{array}$ & $\begin{array}{c}-0.0108 \\
(0.016)\end{array}$ & $\begin{array}{c}0.0143 \\
(0.017)\end{array}$ \\
\hline$\Delta \%$ Under-Rep Students & $\begin{array}{c}-0.1971 \\
(0.207)\end{array}$ & $\begin{array}{c}0.4837^{*} \\
(0.287)\end{array}$ & $\begin{array}{c}-0.8525^{* * *} \\
(0.313)\end{array}$ & $\begin{array}{c}0.0345 \\
(0.163)\end{array}$ \\
\hline$\Delta \%$ Under-Rep Faculty & $\begin{array}{c}1.1910^{* * * *} \\
(0.322)\end{array}$ & $\begin{array}{c}1.5953^{* * * *} \\
(0.365)\end{array}$ & $\begin{array}{l}0.1615 \\
(0.264)\end{array}$ & $\begin{array}{c}0.5642^{*} \\
(0.299)\end{array}$ \\
\hline$\Delta \%$ Under-Rep Administrators & $\begin{array}{c}0.3646^{* *} \\
(0.150)\end{array}$ & $\begin{array}{c}-0.1794 \\
(0.159)\end{array}$ & $\begin{array}{c}-0.0828 \\
(0.163)\end{array}$ & $\begin{array}{c}0.5186^{* * *} \\
\quad(0.178)\end{array}$ \\
\hline Growth in Applicants & $\begin{array}{c}-0.0211 \\
(0.022)\end{array}$ & $\begin{array}{c}-0.0433^{* *} \\
(0.021)\end{array}$ & $\begin{array}{c}-0.0358 \\
(0.027)\end{array}$ & $\begin{array}{c}-0.0348 \\
(0.027)\end{array}$ \\
\hline $\begin{array}{l}\text { Observations } \\
\text { Number of Universities } \\
R^{2}\end{array}$ & $\begin{array}{c}3,262 \\
456 \\
0.014\end{array}$ & $\begin{array}{c}3,392 \\
454 \\
0.015\end{array}$ & $\begin{array}{c}2,005 \\
397 \\
0.074\end{array}$ & $\begin{array}{c}3,181 \\
461 \\
0.024\end{array}$ \\
\hline \multicolumn{5}{|l|}{ Panel B: HBCU Omitted } \\
\hline hief Diversity Officer & $\begin{array}{c}-0.0036 \\
(0.018)\end{array}$ & $\begin{array}{c}-0.0159 \\
(0.017)\end{array}$ & $\begin{array}{c}-0.0119 \\
(0.016)\end{array}$ & $\begin{array}{l}0.0162 \\
(0.018)\end{array}$ \\
\hline$\Delta \%$ Under-Rep Students & $\begin{array}{c}-0.4110 \\
(0.315)\end{array}$ & $\begin{array}{c}0.5003 \\
(0.320)\end{array}$ & $\begin{array}{c}-1.0163^{* * *} \\
(0.390)\end{array}$ & $\begin{array}{c}0.0408 \\
(0.312)\end{array}$ \\
\hline$\Delta \%$ Under-Rep Faculty & $\begin{array}{c}1.4644^{* * * *} \\
(0.406)\end{array}$ & $\begin{array}{c}1.9683^{* * *} \\
(0.457)\end{array}$ & $\begin{array}{l}0.2989 \\
(0.290)\end{array}$ & $\begin{array}{c}0.7210^{*} \\
(0.375)\end{array}$ \\
\hline$\Delta \%$ Under-Rep Administrators & $\begin{array}{c}0.3847^{* *} \\
(0.165)\end{array}$ & $\begin{array}{c}-0.2008 \\
(0.172)\end{array}$ & $\begin{array}{c}-0.0981 \\
(0.170)\end{array}$ & $\begin{array}{c}0.5556^{* * *} \\
\quad(0.190)\end{array}$ \\
\hline Growth in Applicants & $\begin{array}{c}-0.0191 \\
(0.023)\end{array}$ & $\begin{array}{c}-0.0444^{* *} \\
(0.021)\end{array}$ & $\begin{array}{c}-0.0349 \\
(0.028)\end{array}$ & $\begin{array}{c}-0.0333 \\
(0.028)\end{array}$ \\
\hline Observations & 3,154 & 3,298 & 1,960 & 3,089 \\
\hline Number of Universities & 439 & 437 & 381 & 444 \\
\hline$R^{2}$ & 0.015 & 0.017 & 0.076 & 0.025 \\
\hline
\end{tabular}

All specifications include university and annual fixed effects and are estimated in years where hiring demographic reporting is mandatory. Dependent variable is lagged measure of probability for underrepresented minority hires relative to peers. Underrepresented minorities defined as Black, Hispanic, and Native American/Pacific Islander. ${ }^{* * *} p<0.01,{ }^{* *} p<0.05,{ }^{*} p<0.1$. 
Table 7: IV Regressions of CDO on Probability of Diversity Hires Relative to Peer Institutions by Hiring Category

\begin{tabular}{|c|c|c|c|c|c|}
\hline VARIABLES & $\begin{array}{c}(1) \\
\text { First Stage }\end{array}$ & $\begin{array}{c}(2) \\
\text { Non Tenured }\end{array}$ & $\begin{array}{c}(3) \\
\text { Tenure Track }\end{array}$ & $\begin{array}{c}(4) \\
\text { Tenured }\end{array}$ & $\begin{array}{c}(5) \\
\text { Admin }\end{array}$ \\
\hline \multicolumn{6}{|l|}{ Panel A: Full Sample } \\
\hline Chief Diversity Officer & & $\begin{array}{c}-0.0255 \\
(0.038)\end{array}$ & $\begin{array}{l}0.0177 \\
(0.044)\end{array}$ & $\begin{array}{c}-0.0200 \\
(0.033)\end{array}$ & $\begin{array}{c}0.0172 \\
(0.036)\end{array}$ \\
\hline$\Delta \%$ Under-Rep Students & $\begin{array}{l}0.0853 \\
(0.208)\end{array}$ & $\begin{array}{c}-0.1954 \\
(0.207)\end{array}$ & $\begin{array}{c}0.4795^{*} \\
(0.289)\end{array}$ & $\begin{array}{c}-0.8479^{* * *} \\
(0.315)\end{array}$ & $\begin{array}{c}0.0348 \\
(0.163)\end{array}$ \\
\hline$\Delta \%$ Under-Rep Faculty & $\begin{array}{c}-0.9198^{* *} \\
(0.368)\end{array}$ & $\begin{array}{c}1.1723^{* * *} \\
(0.323)\end{array}$ & $\begin{array}{c}1.6107^{* * *} \\
(0.366)\end{array}$ & $\begin{array}{l}0.1557 \\
(0.264)\end{array}$ & $\begin{array}{c}0.5665^{*} \\
(0.302)\end{array}$ \\
\hline$\Delta \%$ Under-Rep Administrators & $\begin{array}{l}0.2401 \\
(0.164)\end{array}$ & $\begin{array}{c}0.3683^{* *} \\
(0.151)\end{array}$ & $\begin{array}{c}-0.1856 \\
(0.160)\end{array}$ & $\begin{array}{c}-0.0826 \\
(0.163)\end{array}$ & $\begin{array}{c}0.5178^{* * *} \\
(0.179)\end{array}$ \\
\hline Growth in Applicants & $\begin{array}{c}-0.0157 \\
(0.027)\end{array}$ & $\begin{array}{c}-0.0212 \\
(0.022)\end{array}$ & $\begin{array}{c}-0.0430^{* *} \\
(0.021)\end{array}$ & $\begin{array}{c}-0.0357 \\
(0.027)\end{array}$ & $\begin{array}{c}-0.0348 \\
(0.027)\end{array}$ \\
\hline Lagged Peer R1 CDOs & $\begin{array}{c}-112.2275^{* * *} \\
(4.081)\end{array}$ & & & & \\
\hline Observations & 3,262 & 3,262 & 3,392 & 2,005 & 3,181 \\
\hline $\begin{array}{l}\text { Number of Universities } \\
R^{2}\end{array}$ & $\begin{array}{c}456 \\
0.492\end{array}$ & 456 & 454 & 397 & 461 \\
\hline First Stage F & & 756.3 & 290.5 & 244.3 & 2100 \\
\hline \multicolumn{6}{|l|}{ Panel B: HBCU Eliminated } \\
\hline Chief Diversity Officer & & $\begin{array}{c}-0.0266 \\
(0.038)\end{array}$ & $\begin{array}{l}0.0177 \\
(0.044)\end{array}$ & $\begin{array}{c}-0.0197 \\
(0.033)\end{array}$ & $\begin{array}{c}0.0179 \\
(0.037)\end{array}$ \\
\hline$\Delta \%$ Under-Rep Students & $\begin{array}{c}-0.0244 \\
(0.374)\end{array}$ & $\begin{array}{c}-0.4111 \\
(0.316)\end{array}$ & $\begin{array}{l}0.4962 \\
(0.322)\end{array}$ & $\begin{array}{c}-1.0117^{* * * *} \\
(0.392)\end{array}$ & $\begin{array}{c}0.0414 \\
(0.313)\end{array}$ \\
\hline$\Delta \%$ Under-Rep Faculty & $\begin{array}{c}-1.1064^{* *} \\
(0.434)\end{array}$ & $\begin{array}{c}1.4406^{* * *} \\
(0.408)\end{array}$ & $\begin{array}{c}1.9977^{* * *} \\
(0.459)\end{array}$ & $\begin{array}{l}0.2909 \\
(0.292)\end{array}$ & $\begin{array}{c}0.7227^{*} \\
(0.377)\end{array}$ \\
\hline$\Delta \%$ Under-Rep Administrators & $\begin{array}{l}0.2631 \\
(0.177)\end{array}$ & $\begin{array}{c}0.3889^{* *} \\
(0.166)\end{array}$ & $\begin{array}{c}-0.2065 \\
(0.173)\end{array}$ & $\begin{array}{c}-0.0971 \\
(0.171)\end{array}$ & $\begin{array}{c}0.5552^{* * *} \\
(0.191)\end{array}$ \\
\hline Growth in Applicants & $\begin{array}{c}-0.0179 \\
(0.028)\end{array}$ & $\begin{array}{c}-0.0192 \\
(0.023)\end{array}$ & $\begin{array}{c}-0.0440^{* *} \\
(0.021)\end{array}$ & $\begin{array}{c}-0.0348 \\
(0.028)\end{array}$ & $\begin{array}{c}-0.0333 \\
(0.028)\end{array}$ \\
\hline Lagged Peer R1 CDOs & $\begin{array}{c}-112.1544^{* * *} \\
(4.073)\end{array}$ & & & & \\
\hline Observations & 3,154 & 3,154 & 3,298 & 1,960 & 3,089 \\
\hline $\begin{array}{l}\text { Number of Universities } \\
R^{2}\end{array}$ & $\begin{array}{c}439 \\
0.503\end{array}$ & 439 & 437 & 381 & 444 \\
\hline First Stage F & & 758.3 & 290.9 & 244.3 & 2126 \\
\hline
\end{tabular}

All specifications include university and annual fixed effects and are estimated in years where hiring demographic reporting is mandatory. Dependent variable is lagged measure of probability for underrepresented minority hires relative to peers. minorities defined as Black, Hispanic, and Native American/Pacific Islander. *** $p<0.01,{ }^{* *} p<0.05,{ }^{*} p<0.1$. 
Table 8: Fixed Effects Regression of CDO and Prior Diversity Trends on Hiring Using Diversity Index

\begin{tabular}{|c|c|c|c|c|}
\hline VARIABLES & $\begin{array}{c}(1) \\
\text { Non Tenured }\end{array}$ & $\begin{array}{c}(2) \\
\text { Tenure Track }\end{array}$ & $\begin{array}{c}(3) \\
\text { Tenured }\end{array}$ & $\begin{array}{c}(4) \\
\text { Admin }\end{array}$ \\
\hline \multicolumn{5}{|l|}{ Panel A: Full Sample } \\
\hline Chief Diversity Officer & $\begin{array}{c}-0.0018 \\
(0.011)\end{array}$ & $\begin{array}{c}-0.0055 \\
(0.010)\end{array}$ & $\begin{array}{c}-0.0104 \\
(0.018)\end{array}$ & $\begin{array}{c}-0.0107 \\
(0.015)\end{array}$ \\
\hline$\Delta$ Student Diversity Index & $\begin{array}{l}0.1281 \\
(0.143)\end{array}$ & $\begin{array}{c}-0.0742 \\
(0.106)\end{array}$ & $\begin{array}{c}-0.0823 \\
(0.200)\end{array}$ & $\begin{array}{c}-0.0592 \\
(0.109)\end{array}$ \\
\hline$\Delta$ Faculty Diversity Index & $\begin{array}{c}0.4115^{* * *} \\
\quad(0.098)\end{array}$ & $\begin{array}{c}0.3656^{* * *} \\
(0.101)\end{array}$ & $\begin{array}{c}0.3114^{*} \\
(0.172)\end{array}$ & $\begin{array}{c}-0.0475 \\
(0.116)\end{array}$ \\
\hline$\Delta$ Administrtor Diversity Index & $\begin{array}{c}-0.0320 \\
(0.079)\end{array}$ & $\begin{array}{c}-0.1255^{* *} \\
(0.060)\end{array}$ & $\begin{array}{c}0.1952^{*} \\
(0.115)\end{array}$ & $\begin{array}{c}0.2878^{* * * *} \\
\quad(0.089)\end{array}$ \\
\hline Growth in Applicants & $\begin{array}{c}-0.0074 \\
(0.017)\end{array}$ & $\begin{array}{c}-0.0053 \\
(0.016)\end{array}$ & $\begin{array}{c}-0.0229 \\
(0.044)\end{array}$ & $\begin{array}{c}-0.0488^{* *} \\
(0.023)\end{array}$ \\
\hline $\begin{array}{l}\text { Observations } \\
\text { Number of Universities } \\
R^{2}\end{array}$ & $\begin{array}{c}3,261 \\
456 \\
0.040\end{array}$ & $\begin{array}{c}3,390 \\
454 \\
0.070\end{array}$ & $\begin{array}{c}2,000 \\
397 \\
0.051\end{array}$ & $\begin{array}{c}3,175 \\
461 \\
0.083\end{array}$ \\
\hline \multicolumn{5}{|l|}{ Panel B: HBCU Omitted } \\
\hline Chief Diversity Officer & $\begin{array}{c}-0.0088 \\
(0.011)\end{array}$ & $\begin{array}{c}-0.0077 \\
(0.010)\end{array}$ & $\begin{array}{c}-0.0152 \\
(0.018)\end{array}$ & $\begin{array}{c}-0.0118 \\
(0.015)\end{array}$ \\
\hline$\Delta$ Student Diversity Index & $\begin{array}{l}0.1848 \\
(0.155)\end{array}$ & $\begin{array}{c}-0.0719 \\
(0.109)\end{array}$ & $\begin{array}{c}-0.0771 \\
(0.207)\end{array}$ & $\begin{array}{c}-0.0223 \\
(0.123)\end{array}$ \\
\hline$\Delta$ Faculty Diversity Index & $\begin{array}{c}0.4136^{* * *} \\
(0.099)\end{array}$ & $\begin{array}{c}0.3813^{* * *} \\
(0.102)\end{array}$ & $\begin{array}{c}0.3593^{* *} \\
(0.173)\end{array}$ & $\begin{array}{c}-0.0542 \\
(0.119)\end{array}$ \\
\hline$\Delta$ Administrtor Diversity Index & $\begin{array}{c}-0.0355 \\
(0.080)\end{array}$ & $\begin{array}{c}-0.1312^{* *} \\
(0.059)\end{array}$ & $\begin{array}{c}0.1622 \\
(0.120)\end{array}$ & $\begin{array}{c}0.2869^{* * *} \\
(0.091)\end{array}$ \\
\hline Growth in Applicants & $\begin{array}{c}-0.0025 \\
(0.017)\end{array}$ & $\begin{array}{c}-0.0075 \\
(0.016)\end{array}$ & $\begin{array}{c}-0.0110 \\
(0.045)\end{array}$ & $\begin{array}{c}-0.0468^{*} \\
(0.025)\end{array}$ \\
\hline $\begin{array}{l}\text { Observations } \\
\text { Number of Universities } \\
R^{2}\end{array}$ & $\begin{array}{c}3,153 \\
439 \\
0.047\end{array}$ & $\begin{array}{c}3,296 \\
437 \\
0.074\end{array}$ & $\begin{array}{c}1,955 \\
381 \\
0.055\end{array}$ & $\begin{array}{c}3,083 \\
444 \\
0.082\end{array}$ \\
\hline
\end{tabular}

All specifications include university and annual fixed effects, and are estimated in years where hiring demographic reporting is mandatory. Dependent variable is lagged Diversity Index for underrepresented minority hires. Underrepresented minorities defined as Black, Hispanic, and Native American/Pacific Islander. ${ }^{* * *} p<0.01,{ }^{* *} p<0.05,{ }^{*} p<0.1$. 
Table 9: IV Regression of CDO and Prior Diversity Trends on Hiring Using Diversity Index

\begin{tabular}{|c|c|c|c|c|c|}
\hline VARIABLES & $\begin{array}{c}(1) \\
\text { First Stage }\end{array}$ & $\begin{array}{c}(2) \\
\text { Non Tenured }\end{array}$ & $\begin{array}{c}(3) \\
\text { Tenure Track }\end{array}$ & $\begin{array}{c}(4) \\
\text { Tenured }\end{array}$ & $\begin{array}{c}(5) \\
\text { Admin }\end{array}$ \\
\hline \multicolumn{6}{|l|}{ Panel A: Full Sample } \\
\hline Chief Diversity Officer & & $\begin{array}{c}0.0060 \\
(0.019)\end{array}$ & $\begin{array}{c}-0.0033 \\
(0.018)\end{array}$ & $\begin{array}{c}-0.0683^{* *} \\
(0.032)\end{array}$ & $\begin{array}{c}-0.0023 \\
(0.027)\end{array}$ \\
\hline$\Delta$ Student Diversity Index & $\begin{array}{l}0.2135 \\
(0.134)\end{array}$ & $\begin{array}{c}0.1262 \\
(0.143)\end{array}$ & $\begin{array}{c}-0.0747 \\
(0.106)\end{array}$ & $\begin{array}{c}-0.0843 \\
(0.207)\end{array}$ & $\begin{array}{c}-0.0621 \\
(0.109)\end{array}$ \\
\hline$\Delta$ Faculty Diversity Index & $\begin{array}{c}-0.1183 \\
(0.127)\end{array}$ & $\begin{array}{c}0.4125^{* * *} \\
(0.098)\end{array}$ & $\begin{array}{c}0.3660^{* * *} \\
(0.101)\end{array}$ & $\begin{array}{c}0.3004^{*} \\
(0.172)\end{array}$ & $\begin{array}{c}-0.0459 \\
(0.117)\end{array}$ \\
\hline$\Delta$ Administrtor Diversity Index & $\begin{array}{c}0.1239 \\
(0.089)\end{array}$ & $\begin{array}{c}-0.0331 \\
(0.079)\end{array}$ & $\begin{array}{c}-0.1256^{* *} \\
(0.060)\end{array}$ & $\begin{array}{c}0.2030^{*} \\
(0.116)\end{array}$ & $\begin{array}{l}0.2869^{* * *} \\
(0.089)\end{array}$ \\
\hline Growth in Applicants & $\begin{array}{c}-0.0141 \\
(0.027)\end{array}$ & $\begin{array}{c}-0.0073 \\
(0.017)\end{array}$ & $\begin{array}{c}-0.0052 \\
(0.016)\end{array}$ & $\begin{array}{c}-0.0227 \\
(0.044)\end{array}$ & $\begin{array}{c}-0.0488^{* *} \\
(0.023)\end{array}$ \\
\hline Lagged Peer R1 CDOs & $\begin{array}{c}-112.0672^{* * *} \\
(4.080)\end{array}$ & & & & \\
\hline $\begin{array}{l}\text { Observations } \\
\text { Number of Universities } \\
R^{2}\end{array}$ & $\begin{array}{c}3,261 \\
456 \\
0.492\end{array}$ & $\begin{array}{c}3,261 \\
456\end{array}$ & $\begin{array}{c}3,390 \\
454\end{array}$ & $\begin{array}{c}2,000 \\
397\end{array}$ & $\begin{array}{c}3,175 \\
461\end{array}$ \\
\hline \multicolumn{5}{|l|}{ Panel B: HBCU Omitted } & 282.9 \\
\hline Chief Diversity Officer & & $\begin{array}{c}0.0036 \\
(0.019)\end{array}$ & $\begin{array}{c}-0.0045 \\
(0.018)\end{array}$ & $\begin{array}{c}-0.0674^{* *} \\
(0.032)\end{array}$ & $\begin{array}{c}-0.0050 \\
(0.027)\end{array}$ \\
\hline$\Delta$ Student Diversity Index & $\begin{array}{c}0.2829^{*} \\
(0.151)\end{array}$ & $\begin{array}{l}0.1811 \\
(0.155)\end{array}$ & $\begin{array}{c}-0.0728 \\
(0.109)\end{array}$ & $\begin{array}{c}-0.0783 \\
(0.213)\end{array}$ & $\begin{array}{c}-0.0253 \\
(0.122)\end{array}$ \\
\hline$\Delta$ Faculty Diversity Index & $\begin{array}{c}-0.1233 \\
(0.131)\end{array}$ & $\begin{array}{c}0.4152^{* * *} \\
\quad(0.099)\end{array}$ & $\begin{array}{c}0.3819^{* * *} \\
(0.102)\end{array}$ & $\begin{array}{c}0.3508^{* *} \\
(0.173)\end{array}$ & $\begin{array}{c}-0.0529 \\
(0.119)\end{array}$ \\
\hline$\Delta$ Administrtor Diversity Index & $\begin{array}{l}0.1344 \\
(0.094)\end{array}$ & $\begin{array}{c}-0.0373 \\
(0.079)\end{array}$ & $\begin{array}{c}-0.1314^{* *} \\
\quad(0.058)\end{array}$ & $\begin{array}{l}0.1680 \\
(0.122)\end{array}$ & $\begin{array}{l}0.2860^{* * *} \\
(0.091)\end{array}$ \\
\hline Growth in Applicants & $\begin{array}{c}-0.0170 \\
(0.028)\end{array}$ & $\begin{array}{c}-0.0024 \\
(0.017)\end{array}$ & $\begin{array}{c}-0.0075 \\
(0.016)\end{array}$ & $\begin{array}{c}-0.0103 \\
(0.045)\end{array}$ & $\begin{array}{c}-0.0468^{*} \\
(0.025)\end{array}$ \\
\hline Lagged Peer R1 CDOs & $\begin{array}{c}-111.9941^{* * *} \\
(4.070)\end{array}$ & & & & \\
\hline Observations & 3,153 & 3,153 & 3,296 & 1,955 & 3,083 \\
\hline $\begin{array}{l}\text { Number of Universities } \\
R^{2}\end{array}$ & $\begin{array}{c}439 \\
0.502\end{array}$ & 439 & 437 & 381 & 444 \\
\hline First Stage F & & 757.3 & 290.9 & 244.5 & 281.5 \\
\hline
\end{tabular}

All specifications include university and annual fixed effects, and are estimated in years where hiring demographic reporting is mandatory. Dependent variable is lagged Diversity Index for underrepresented minority hires. Underrepresented minorities defined as Black, Hispanic, and Native American/Pacific Islander. ${ }^{* * *} p<0.01,{ }^{* *} p<3$ (9.05, ${ }^{*} p<0.1$. 
Table 10: Diverse Hiring in 2016 by Carnegie Classification, Urbanization, and Census Region

\begin{tabular}{|c|c|c|c|c|}
\hline VARIABLES & $\begin{array}{c}(1) \\
\text { Full } \\
\text { Sample } \\
\text { mean } \\
(\mathrm{sd}) \\
\end{array}$ & $\begin{array}{c}(2) \\
\text { Carnegie } \\
F \\
(p \text {-value }) \\
\end{array}$ & $\begin{array}{c}(3) \\
\text { Urbanization } \\
F \\
(p \text {-value }) \\
\end{array}$ & $\begin{array}{c}(4) \\
\text { Census } \\
\text { Region } \\
F \\
(p \text {-value }) \\
\end{array}$ \\
\hline Pct Black Non-Tenured Hired & $\begin{array}{l}0.0761 \\
(0.147)\end{array}$ & $\begin{array}{c}1.56 \\
(0.212)\end{array}$ & $\begin{array}{l}2.13^{* *} \\
(0.026)\end{array}$ & $\begin{array}{c}7.67^{* * *} \\
(0.000)\end{array}$ \\
\hline Pct Hispanic Non-Tenured Hired & $\begin{array}{l}0.0530 \\
(0.0998)\end{array}$ & $\begin{array}{c}0.22 \\
(0.805)\end{array}$ & $\begin{array}{c}1.19 \\
(0.298)\end{array}$ & $\begin{array}{c}4.79^{* * *} \\
(0.003)\end{array}$ \\
\hline Pct Native Non-Tenured Hired & $\begin{array}{c}0.00810 \\
(0.0555)\end{array}$ & $\begin{array}{c}0.05 \\
(0.954)\end{array}$ & $\begin{array}{c}1.32 \\
(0.224)\end{array}$ & $\begin{array}{c}1.68 \\
(0.170)\end{array}$ \\
\hline Pct Under-Rep Non-Tenured Hires & $\begin{array}{l}0.137 \\
(0.185)\end{array}$ & $\begin{array}{c}0.40 \\
(0.673)\end{array}$ & $\begin{array}{l}1.70^{*} \\
(0.087)\end{array}$ & $\begin{array}{l}2.59^{*} \\
(0.053)\end{array}$ \\
\hline Observations & 430 & & & \\
\hline Pct Black Tenure Track Hired & $\begin{array}{l}0.0698 \\
(0.137)\end{array}$ & $\begin{array}{l}2.52^{*} \\
(0.082)\end{array}$ & $\begin{array}{c}1.13 \\
(0.339)\end{array}$ & $\begin{array}{c}0.92 \\
(0.430)\end{array}$ \\
\hline Pct Hispanic Tenure Track Hired & $\begin{array}{l}0.0433 \\
(0.0574)\end{array}$ & $\begin{array}{c}0.10 \\
(0.901)\end{array}$ & $\begin{array}{c}0.82 \\
(0.606)\end{array}$ & $\begin{array}{c}9.54^{* * *} \\
(0.000)\end{array}$ \\
\hline Pct Native Tenure Track Hired & $\begin{array}{c}0.00361 \\
(0.0143)\end{array}$ & $\begin{array}{c}0.02 \\
(0,984)\end{array}$ & $\begin{array}{c}0.52 \\
(0.874)\end{array}$ & $\begin{array}{c}0.85 \\
(0.467)\end{array}$ \\
\hline Pct Under-Rep Tenure-Track Hires & $\begin{array}{c}0.117 \\
(0.143)\end{array}$ & $\begin{array}{c}2.18 \\
(0.114)\end{array}$ & $\begin{array}{c}1.31 \\
(0.222)\end{array}$ & $\begin{array}{l}2.26^{*} \\
(0.081)\end{array}$ \\
\hline Observations & 443 & & & \\
\hline Pct Black Tenured Hired & $\begin{array}{r}0.0737 \\
(0.198)\end{array}$ & $\begin{array}{c}1.37 \\
(0.256)\end{array}$ & $\begin{array}{c}0.68 \\
(0.745)\end{array}$ & $\begin{array}{c}0.43 \\
(0.731)\end{array}$ \\
\hline Pct Hispanic Tenured Hired & $\begin{array}{c}0.0416 \\
(0.134)\end{array}$ & $\begin{array}{c}0.06 \\
(0.937)\end{array}$ & $\begin{array}{c}1.14 \\
(0.330)\end{array}$ & $\begin{array}{c}1.94 \\
(0.123)\end{array}$ \\
\hline Pct Native Tenured Hired & $\begin{array}{c}0.00237 \\
(0.0158)\end{array}$ & $\begin{array}{c}1.38 \\
(0.253)\end{array}$ & $\begin{array}{c}1.36 \\
(0.198)\end{array}$ & $\begin{array}{c}0.68 \\
(0.563)\end{array}$ \\
\hline Pct Under-Rep Tenured Hires & $\begin{array}{l}0.118 \\
(0.229)\end{array}$ & $\begin{array}{c}0.81 \\
(0.444)\end{array}$ & $\begin{array}{c}0.69 \\
(0.733)\end{array}$ & $\begin{array}{c}1.45 \\
(0.229)\end{array}$ \\
\hline Observations & 275 & & & \\
\hline Pct Black Administrators Hired & $\begin{array}{l}0.138 \\
(0.202)\end{array}$ & $\begin{array}{l}2.98^{*} \\
(0.052)\end{array}$ & $\begin{array}{c}0.57 \\
(0.836)\end{array}$ & $\begin{array}{l}2.18^{*} \\
(0.089)\end{array}$ \\
\hline Pct Hispanic Administrators Hired & $\begin{array}{l}0.0547 \\
(0.0992)\end{array}$ & $\begin{array}{c}0.40 \\
(0.672)\end{array}$ & $\begin{array}{l}2.16^{* *} \\
(0.019)\end{array}$ & $\begin{array}{l}3.00^{* *} \\
(0.030)\end{array}$ \\
\hline Pct Native Administrators Hired & $\begin{array}{c}0.00353 \\
(0.0202)\end{array}$ & $\begin{array}{c}6.05^{* * *} \\
(0.003)\end{array}$ & $\begin{array}{c}1.14 \\
(0.333)\end{array}$ & $\begin{array}{l}2.91^{* *} \\
(0.034)\end{array}$ \\
\hline Pct Under-Rep Administrator Hires & $\begin{array}{c}0.196 \\
(0.220)\end{array}$ & $\begin{array}{c}0.99 \\
(0.373)\end{array}$ & $\begin{array}{c}1.38 \\
(0.188)\end{array}$ & $\begin{array}{l}2.13^{*} \\
(0.096)\end{array}$ \\
\hline Observations & 446 & & & \\
\hline CDO In Place & $\begin{array}{c}0.67634 \\
(0.468)\end{array}$ & $\begin{array}{c}17.85^{* * *} \\
(0.000)\end{array}$ & $\begin{array}{c}2.56^{* * *} \\
(0.005)\end{array}$ & $\begin{array}{c}1.03 \\
(0.379)\end{array}$ \\
\hline Observations & 448 & & & \\
\hline
\end{tabular}

Notes: Column 1 contains means and standard deviations of indicated variables for the 2016 academic hiring cycle. HBCU institutions are omitted. Carnegie categories are R1, R2, and M1. 11 Urbanization classifications range from Large City to Distant Rural area. Census Regions are Northeast, Midwest, South, and West. Each cell in columns 2 - 4 reports an $F$-test of difference of means by indicated category. ${ }^{* * *} p<0.01,{ }^{* *} p 4 \& 0.05,{ }^{*} p<0.1$. 